\title{
A REGIONAL PERSPECTIVE OF THE CREATIVE ECONOMY IN BRAZIL
}

Jorge Nogueira de Paiva Britto

\section{Introduction}

For the United Nations Conference on Trade and Development (UNCTAD), the Creative economy is an evolving concept based on creative assets potentially generating economic growth and development (2008; 2010). In a broader definition, the Creative Economy consists of creative industries' transactions that includes at the core creative people expressing a personal aesthetic in his/her work, comprising collaborative processes between creativity, technology and business. This economy would be structured from the generation of functional products and services, which encompass both formal and informal activities, as well as industrial and non-industrial sect. It is assumed that, at the productive orbit, Creative Industries are among the most dynamic sectors of the world economy, presenting a huge potential to boost national economies generating jobs, income and development, due to crosscutting linkages at macro and micro levels to the overall economy, while promoting social inclusion, cultural diversity and human development. In the policy sphere, the Creative Economy would be defined as set of knowledge-based economic activities with a development dimension, which constitutes a feasible development option for innovation, multidisciplinary policy responses and inter-ministerial action.

Initiatives based on Creative Economy have promoted economic diversification, trade and innovation in various countries and regions, contributing to the revitalization of degraded urban areas, to the development and promotion of remote rural areas and to the conservation of cultural and natural heritage (UNCTAD 2010). At the same time, evidence shows that countries with denser creative economies have recovered more quickly from the challenges posed by the increasing globalization (Stolarick et al., 2010). To developing countries, creative activities also represent a catalyst for a more comprehensive, balanced and inclusive development, creating well-being and reinforcing more resilient paths of economic growth. In this sense, they can create jobs that are less susceptible to fluctuations of the global economy, which tend to be labor intensive instead of capital intensive, generating positive externalities and constituting a basis of a local, sustainable and all-inclusive development, contributing to a better quality of life.

In Brazil, the Secretariat of the Creative Economy defines as attributes of creative activities the possibilities of innovation, the perspectives of productive and social Inclusion, the exploitation of the potential of cultural diversity and the concern with the sustainability of those activities for future generations. In this perspective, a set of "core" Creative Sectors are mentioned, as well as the relevance of preserving the cultural intangible heritage. A focus on those activities would be articulate to the design of public policies oriented to the aim of reducing socio-economic and regional inequalities, spreading the dissemination of those activities throughout the territory, especially in the direction of less favored regions. In this context, it is worth asking whether this expansion has induced an effective reduction of regional imbalances in terms of the quality of the jobs created and of the level of remuneration generated by those activities.

Considering these aspects, the article comprises three blocks. The first section presents a synthesis of the main approaches that try to characterize creative activities and to develop sectoral classifications to them. The second section presents a general framework of the creative activities in the Brazilian economy, stressing the criteria applied by policy instances to classify those activities and presenting some results of studies and evaluations that have attempted to estimate the size of the Creative Economy in Brazil. The third section presents an attempt to identify inter-sectoral trends related to the regional distribution of creative activities in Brazil. A conclusive section summarizes some policy implications generated from the analysis. 


\section{1 - Defining the Creative Economy: general approaches}

The creative economy concept first appeared in John Howkins' 2001 book, The Creative Economy: How People Make Money From Ideas, where he defined the creative economy as "the transactions of creative products that have an economic good or service that results from creativity and has economic value" (p. 8). The term creative economy was applied to 15 industries extending from the arts to science and technology, including all the sectors whose goods and services are based on intellectual property: advertising, architecture, crafts, design, fashion, film, games and toys, music, publishing, research and development, software, TV and radio, and videogames, and visual and performing arts.

The notion embraces not only essentially "cultural" goods and services - which have at their core a symbolic or expressive element, encompassing a wide range of fields, such as music, art, writing, fashion and design, as well as media industries - but also toys and games and the entire domain of "research and development" (R\&D), which requires some reasonably significant level of creativity. In this definition, technological change and digitalization has overtaken the old concept of the "cultural industries", which was strongly focused on the "arts" plus the commercial media (film, broadcasting, music). While recognizing cultural activities as the core of a powerful new economy, it is also concerned with manifestations of creativity in domains that would not be understood as "cultural", which would be coherent with a broader definition of a "knowledge economy". These industries lie at the crossroads between the arts, business and technology (UNCTAD, 2008), having the cultural industries as a subset (O’Reagan, 2001; Cunningham, 2002). The term has become more generally used to denote activities whose main attribute is continuous novelty and whose values are expressive or relevant. These activities are creative, expressive and innovative but not necessarily cultural, referring to a product's entire value, as in a painting or song, or being combined with functional elements, such as in media or software.

An attempt to reconcile the "artistic" and "creative" dimensions of those activities can be found in the analysis developed by Florida (2002, 2005, 2006). In this approach, the notions of emerging creative class and creative entrepreneurs have considerably broadened the notion to include a cohort of professional, scientific and artistic workers whose presence generates economic, social and cultural dynamism. Creative industries are highly specialized users of creative workers, whose talent would be mobilized for commercial purposes. This "creative class" is a very capacious grouping of many different kinds of professional, managerial and technical workers (not just creative workers in the cultural and creative industries), producing innovation of various types. Recent research has provided more evidence about the connection between creativity and innovation, including the role of artistic labor with attitudes and skills that are conducive to innovation, generating widespread impacts through a process of 'culturalization' of activities. In this context, an effective policy might understand the relationship between the arts and the creative industries, recognizing and encouraging the complexity though which the various components overlap, collaborate and coexist.

Some dimensions of creativity might be mentioned (UNCTAD, 2010). Artistic creativity involves imagination and a capacity to generate original ideas and novel ways of interpreting the world, expressed in text, sound and image. Scientific creativity involves curiosity and a willingness to experiment and make new connections in problem solving. The broader concept of Economic creativity refers to a dynamic process leading towards innovation in technology, business practices, marketing, etc., which is closely linked to gaining competitive advantages in the economy. Another aspect refers to the relevance of some enabling factors for the development of the Creative Economy. Among these factors, we can mention the provision of infrastructure, particularly ICT and transportation, the availability of social and cultural spaces/amenities and the quality of educational systems, especially to the development of creative skills. An institutional framework that protects individuals' rights and is tolerant towards cultural and social diversity seems also to be relevant, as well as the presence of intellectual property rights regimes that reward creativity and protect local creators in global markets. At the policy sphere, we can mention the support for small and medium sized enterprises to ensure that creative industries as an economic driver are wide-spread, as well as the support to existing creative clusters, which could allow smaller innovative and creative firms to be incorporated as part of a larger industry. At the regulatory level, we 
can mention the relevance of frameworks and instruments that promote access into the field of those ndustries by creative entrepreneurs.

The "Economic" Rationale of the Creative Economy remains in the hypothesis that creative industries are a major economic driver, generating faster economic growth, employment and job creation. Their growing relevance reflect a transformation from a manufacturing-based economy to a knowledgebased economy. In this sense, cultural/creative industries offers new responses and opportunities in a globalized context, not only driving growth through the creation of value, but also becoming key elements of the innovation system of the entire economy. In this context, their primary significance stems from the ways in which they stimulate the emergence of new ideas or technologies, and the processes of structural change.

To developing countries, the improvement of the Creative Economy has an economic potential for wealth creation as a source of jobs, revenues and currencies for exports, but also a catalyst for a more comprehensive and balanced development, creating well-being and reinforcing a process of inclusive development at local, regional and national levels. A study elaborated by SELA (2013) argued that cultural industries might be particularly relevant to developing countries, with culture constituting an available resource in the fight against inequality and poverty, generating employment choices for indigenous people and to vulnerable or sidelined groups. In this perspective, culture not only represents a potential for creating jobs and revenues but also creates positive externalities, being flexible to be developed both in the rural and urban slums, benefiting the poorer groups of society. At the same time, culture plays an important role in recreating cities as safe living spaces that instill in their residents a sense of responsibility and belonging, contributing to reduce territorial inequalities.

Four different approaches are usually applied to characterize and to measure the dimensions of a creative economy. The sectoral approach defines the specific types of production that should be included in definitions of a creative economy, focusing on the characterization and analysis of creative industries. The labor market and organization of production approach focused on the flexible specialization of communities of workers with 'special competencies or distinct-like capacities' (Scott, 2004). Florida (2002) pointed the emergence of a 'creative class' as a discrete segment of society, employed in the creative industries, but also found in $R \& D$ and other 'creative' occupations across all industries. The 'creative index' approach focus on a broader set of economic activities with a creative element, measuring their impact on urban and regional economies. This perspective stress the possibility of associating the relevance of those activities with a creative index, including the computation of indices such as a bohemian index, gay index and so forth. It also stress the "convergence of formats" as a defining feature of the creative economy, directing the focus to the media through which creative products are consumed, which are increasingly reliant upon a common digital platform, stimulating the amalgamation of arts, popular culture, telecommunications and broadcasting. Finally, the approach of "locational proclivities" emphasizes the spatial organization and geography of specific forms of cultural production in particular localities, reflecting a process of agglomeration, clustering or metropolitan primacy. This approach assumes that creativity and innovation in the modern cultural economy can be understood as social phenomena rooted in a local production system and its geographic milieu. In this perspective, creative activities, at the same, time tend to be root and has the capacity to transform urban locations.

Different models can be encountered in literature to illustrate the ways in which the creative industries are defined and have been refined over time. These models illustrates the relationships between the various components that make up the creative economy, which are not straightforward and can be understood in multiple ways. The original characterization elaborate by Howkins (2001) outlines 15 industries that contribute to the creative economy by generating creative products and services, ranging from the arts to science and technology, which results from creativity and has economic value. The UK DCMS model defines the creative industries as those requiring "creativity, skill and talent with the potential for wealth and job creation through the exploitation of their intellectual property" (DCMS, 1998). The Concentric Circles model developed by Throsby (2001) assumes that creative ideas originate in the core creative arts and that these ideas and influences diffuse outwards through a series of layers or concentric circles, with the proportion of cultural to commercial content decreasing as one moves outwards from the center. The UNESCO definition of Cultural Economy (2013) distinguishes six main 
cultural domains - Natural Heritage; Performance and Celebration; Visual Arts and Crafts; Books and Press; Audio-visual and Interactive Media; Design and Creative Services - as well as two related domains - Tourism and Sports and Recreation- and the support of activities related to strengthening of intangible cultural heritage, education and training, archiving and preserving and the provision of equipment and supporting materials. The WIPO copyright model (2003) stands the role industries involved directly or indirectly in the creation, manufacture, production, broadcast and distribution of copyrighted material.

Among these models, we can stand the approach developed by UNCTAD, which incorporate an attempt to capture the multiplicity of realities concerning the structure and the dynamism of creative economies. The UNCTAD model $(2008,2010,2013)$ enlarges the concept of 'creativity' from activities having a strong artistic component to any economic activity producing symbolic goods and services that use creativity and intellectual capital as primary inputs. At the heart of the creative economy, the UNCTAD model identify the presence of creative industries, which could be classified in four large groups. Activities related to the cultural Heritage are identified as the origin of all forms of arts and the soul of cultural and creative industries. It is heritage that brings together cultural aspects from the historical, anthropological, ethnic, aesthetic and societal viewpoints. This group is therefore divided into two subgroups: (i) Traditional cultural expressions: art crafts, festivals and celebrations; (ii) Cultural sites: archaeological sites, museums, libraries, exhibitions, etc. The group of Arts includes creative industries based purely on art and culture, being divided into two large subgroups: (i) Visual arts: painting, sculpture, photography and antiques; (ii) performing arts: live music, theatre, dance, opera, circus, puppetry, etc. The group of Media covers two subgroups that produce creative content with the purpose of communicating with large audiences (the "new media" is classified separately): (i) Publishing and printed media: books, press and other publications; (ii) Audiovisuals: film, television, radio and other broadcasting. The broader group of Functional creations comprises more demand-driven and servicesoriented industries that create creative goods and services with functional purposes. It is divided into the following subgroups: (i) Design: interior, graphic, fashion, jewellery, toys; (ii) New media: architectural, advertising, cultural and recreational, creative research and development (R\&D), digital and other related creative services; (iii) Creative services: architectural, advertising, cultural and recreational, creative research and development (R\&D), digital and other related creative services. There is an ongoing debate about whether science and $R \& D$ are components of the creative economy, and whether creative experimentation activities can be considered $R \& D$. Recent empirical research has strengthened the relevance of the interactions between research, science and the dynamics of the creative economy.

\section{2 - Creative Activities in the Brazilian Economy}

According to the definition of the Brazilian Secretariat of the Creative Economy of the Ministry of Culture, creative industries are defined as "[...] all those productive activities whose mainly process involve a creative act generator of symbolic value, which constitutes a central element of price formation, and resulting in the production of cultural and economic wealth." (SEC 2011, p. 22). This Secretariat also argues that "Creative Economy from the cultural, social and economic dynamics comprises the cycle of creation, production, distribution / circulation / dissemination and consumption / enjoyment of goods and services from the creative sectors characterized by the prevalence of its symbolic dimension". (2011, p.23).

In this perspective, four attributes are mentioned as guiding principles to define creative activities: 1) Innovation: comprises improvements (incremental innovations) and the creation of something totally new (radical innovation), being related to the identification of relevant and workable solutions, especially in the creative sectors whose products are the result of the integration of new technologies and cultural content; 2) Social Inclusion: stresses the promotion of productive inclusion of the population through training and professional qualification and the generation of job opportunities and income, also assuming that the access to creative goods and services emerges as a premise for citizenship; 3) Cultural Diversity: assumes that the growth of the Brazilian creative economy must includes the recovery, protection and promotion of the diversity of national cultural expressions in order to ensure their originality, their strength and their potential; 4) Sustainability: comprises an evaluation of what kind 
of development would be desired, including a management of the stages of this development and to ensure social, cultural, environmental and economic reproduction of those activities for future generations.

To orient a definition of an effective set of policies the Brazilian Secretariat of the Creative Economy identifies six "core" Creative Sectors: 1) Natural and Cultural Heritage; 2) Spectacles and Celebrations; 3) Visual Arts and Crafts; 4) Books and Periodicals; 5) Audiovisual and Interactive Media; 6) Design and Creative Services. Additionally, two related creative sectors are mentioned: Tourism and Sports/Leisure. It also mention the relevance of preserving the Intangible Heritage (including oral traditions and expressions, rituals, languages and social practices), improving the general conditions of Education and Training and availability of equipment and support materials.

In recent years, various studies and evaluations have attempted to estimate the size of the Creative Economy in Brazil. Studies prepared by FIRJAN have tried to define scale of the creative industry in Brazil, with the purpose of measuring its economic importance. Based on the UNCTAD definition of creative industry, the last version of the FIRJAN study (2014) propose a definition of the creative industry that identify four major areas and their respective segments: 1) Consumption (Advertising, Architecture, Design and Fashion); 2) Culture (Cultural expressions, Heritage and arts, Music, Performing arts); 3) Media (Editorial, Audio-visual); 4) Technology (R\&D, ICT, Biotechnology). According to FIRJAN (2014), 251.000 companies formed the core of the Brazilian creative industry in 2013. Over the last decade, there was an increase of $69.1 \%$ since 2004, when they were 148.000 companies. Based on amount of salaries generated by those companies, it is estimated that the creative core activities generates a gross domestic product equivalent to $\mathrm{R} \$ 126$ billion, equivalent to $2.6 \%$. of the overall production in Brazil in 2013, compared to 2.1\% in 2004. During this period, the GDP of Creative Industry advanced $69.8 \%$ in real terms, compared to an advance of $36.4 \%$ of the GDP in the same decade (Table 1).

Table 1 - Creative GDP Estimate and Its Contribution to Brazilian GDP Total - 2004-2013

\begin{tabular}{|c|c|c|}
\hline Year & $\begin{array}{c}\text { Creative GDP (R\$ } \\
\text { billion) }\end{array}$ & \% of Brazilian GDP \\
\hline 2004 & 74,3 & $2,09 \%$ \\
\hline 2005 & 80,7 & $2,20 \%$ \\
\hline 2006 & 86,0 & $2,26 \%$ \\
\hline 2007 & 89,3 & $2,21 \%$ \\
\hline 2008 & 100,6 & $2,37 \%$ \\
\hline 2009 & 100,7 & $2,38 \%$ \\
\hline 2010 & 111,9 & $2,46 \%$ \\
\hline 2011 & 116,4 & $2,49 \%$ \\
\hline 2012 & 120,6 & $2,55 \%$ \\
\hline 2013 & 126,1 & $2,60 \%$ \\
\hline
\end{tabular}

Source: FIRJAN (2014)

Also according to the FIRJAN (2014) study, the Brazilian creative industries comprise 892.500 formal workers in 2013. Between 2004 and 2013, there was an increase of 90\% in the jobs generated by those industries, well above the advance of 56\% observed for the entire labor market during this period (Table 2). Thus, the participation of the creative workers in the total of the Brazilian formal workers was $1.8 \%$ in 2013, compared to $1.5 \%$ in 2004 . The Architecture \& Engineering segment is the one with the largest representation, concentrating more than a quarter $(230,000)$ of this universe. Soon after come the segments of Advertising and Design employing more than 100,000 workers each. Together, these three sectors concentrate half of Brazilian creative workers. With regard to the salaries, while the average monthly income of Brazilian workers was 2.073 in 2013, for creative professionals they reached R\$ 5.422, almost three times the national level. Compared to 2004, the salaries of the creative class were already well above the national average: there was a real growth of $25.4 \%$ to creative activities, following the significant increase of the Brazilian worker income in that period (29.8\%). Among the creative segments, the most numerous in terms of professionals also had the highest average wages - Research \& Development (R\$ 9.990), Architecture (R\$ 6.927), ICT (R\$ 5.393) and Advertising (R\$ 5.075. Already compared to 2004, the highest real wage increases occurred in the segments less pay: Fashion (42.1\%), Music (33.3\%), Audiovisual (32.7\%) and Cultural Expressions (31.6\%). 
Table 2 - Jobs and Salaries in Brazilian Creative Industries - 2004 and 2013

\begin{tabular}{|c|c|c|c|c|c|c|}
\hline Segments & 2004 & 2013 & Growth & 2004 & 2013 & Growth \\
\hline 1) Consumption & 211,5 & 422,9 & $100,0 \%$ & 3.619 & 4.653 & $28,6 \%$ \\
\hline Advertising & 45,7 & 154,8 & $238,5 \%$ & 5.354 & 6.927 & $29,4 \%$ \\
\hline Architecture & 62,7 & 124,5 & $98,5 \%$ & 5.701 & 5.075 & $-11,0 \%$ \\
\hline Design & 42,6 & 87,0 & $104,3 \%$ & 2.556 & 2.760 & $8,0 \%$ \\
\hline Fashion & 60,5 & 56,7 & $-6,3 \%$ & 993 & 1.412 & $42,1 \%$ \\
\hline 2) Culture & 43,3 & 62,1 & $43,6 \%$ & 1.962 & 2.527 & $28,8 \%$ \\
\hline Cultural expressions & 18,3 & 22,5 & $22,7 \%$ & 2.880 & 3.721 & $29,2 \%$ \\
\hline Heritage and arts & 10,2 & 16,4 & $60,9 \%$ & 3.047 & 3.157 & $3,6 \%$ \\
\hline Music & 7,5 & 12,0 & $60,4 \%$ & 1.662 & 2.216 & $33,3 \%$ \\
\hline Performing arts & 7,2 & 11,2 & $54,9 \%$ & 1.146 & 1.508 & $31,6 \%$ \\
\hline 3) Media & 64,2 & 101,4 & $58,0 \%$ & 2.670 & 3.080 & $15,4 \%$ \\
\hline Editorial & 27,8 & 50,8 & $82,5 \%$ & 3.829 & 3.794 & $-0,9 \%$ \\
\hline Audio-visual & 36,3 & 50,6 & $39,1 \%$ & 1.782 & 2.364 & $32,7 \%$ \\
\hline 4) Technology & 150,9 & 306,1 & $102,8 \%$ & 6.688 & 7.848 & $17,3 \%$ \\
\hline R\&D & 82,2 & 166,3 & $102,3 \%$ & 3.791 & 4.911 & $29,6 \%$ \\
\hline ICT & 55,5 & 112,9 & $103,6 \%$ & 8.344 & 9.990 & $19,7 \%$ \\
\hline Biotechnology & 13,2 & 26,9 & $102,8 \%$ & 4.926 & 5.393 & $9,5 \%$ \\
\hline Creative Industries & 469,8 & 892,5 & $90,0 \%$ & 4.323 & 5.422 & $25,4 \%$ \\
\hline
\end{tabular}

Source: FIRJAN (2014)

Another study elaborated by Oliveira, Araujo and Silva to IPEA (2013) also presents an estimation of the size of the Creative Economy in Brazil, both to the formal and for the informal sectors. To measure this size, two dimensions are used and two approaches are developed. The two different dimensions comprises the productive sector - where the focus is the creative character of the economic activity - and the occupational dimension of the creative classes - where the focus is on the occupation exercised by the employee. The approaches comprises the formal economy, based on data from the Annual Report of Social Information (RAIS) of the Ministry of Labor and Employment (MTE), and the formal and informal economy, based on data from the National Household Survey (PNAD), carried out by the Brazilian Institute of Geography and Statistics (IBGE). The identification of economic sectors that define the creative economy also comprises the use of data from the Annual Survey of Services (PAS) carried by IBGE, allowing an estimation of the value added by enterprises in creative industries, in order to identify the participation of the creative economy in the Brazilian GDP.

In IPEA study, the data from PNAD-IBGE is used to measure the size of formal and informal creative economy in the period 2006-2010. The number of workers in the creative economy would be around $2 \%$ according to both criteria: according to the occupational criterion, the creative industry employed 575,000 workers in 2010; where according to the sectoral criterion it reach 583,000 employees. According to the sectoral criterion, the sectors that employ more are publishing and print media, new media, creative services and audiovisual. According to the occupational criterion, workers are mostly in occupations linked to the creative and design services. It should be also noted that there are several creative services workers (among which include, among others, architects and teaching professionals) as well as designers in companies whose core business is not exactly tied to the creative economy. In order to assess the extent of the creative economy, IPEA study used the data from PAS-IBGE corrected by the proportionality of the creative occupations derived from the RAIS to estimate the Value Added (VA) generated by the creative industries in Brazil in 2009, presented in Table 4. According to this procedure, the VA of the Brazilian creative economy corresponded to $1.1 \%$ of GDP. When comparing the VA generated by the creative industries with the VA of total economy in 2009 , we get $1.2 \%$. It should be noted that this comparison does not incorporate the informal dimension of creative activities in the Brazilian economy.

\section{3 - Regional Distribution of Creative Activities in Brazil}

The following analysis presents an attempt to map of the regional distribution of jobs and remunerations in creative activities in Brazil. Two basic sources of information were used: i) data from Decennial Census of 2010 carried out by IBGE; iii) information about formal jobs extracted from RAIS, the Annual Report of Social Information provided by the Brazilian Ministry of Labor and Employment. 
It should be noted that the criterion used to identify creative activities have been adapted to take into account the classification of economic activities provided by these databases. In the case of the 2010 Census, which includes information collected directly from household units, eight activities were considered: 1) Publishing and printing; 2) Film and video production, television shows, sound recording and music; 3) Radio and television; 4) Information technology and services; 5) Architectural and engineering activities and related technical tests and analysis; 6) Advertising agencies; 7) Artistic activities, creative activities and spectacles; 8) Activities related to cultural heritage and environmental. Concerning the data from RAIS, which include information about formal jobs collected from business units, eleven activities were considered: 1) Publishing and Printing; 2) Film, video and music; 3) Radio and TV; 4) Software development; 5) Architectural services; 6) Advertising agencies; 7) Design and interior decoration; 8) Photographic and similar activities; 9) Performing activities; 10) Activities related to cultural heritage; 11) Activities of membership organizations linked to culture and art.

\subsection{Jobs}

According to the 2010 Brazilian decennial Census, approximately 1.7 million jobs were concentrated in creative activities (Table 5), which accounted for $1.9 \%$ of the total occupations in that Census (approximately 83.6 million). The largest share of those jobs were concentrated on Information technologies and services (with 518.755 occupations, equivalent to $0.6 \%$ of the overall occupations and to $31.0 \%$ of occupations in creative activities), followed by Architectural and engineering activities and related technical analyzes (with 364.565 occupations, equivalent to $0.4 \%$ of the overall occupations and to 21.8\% of occupations in creative activities) and by Artistic activities, creative and spectacles (with 290.257 occupations, equivalent to $0.3 \%$ of the overall occupations and to $17.3 \%$ of occupations in creative activities).

With regard to regional distribution, according to the Census, $57.2 \%$ of the occupations in creative activities were concentrated in the Southeast, against $44.1 \%$ for the overall occupations, making the participation of creative activities in that region to rise to $2.5 \%$. In terms of distribution by federative states in the region, $34.4 \%$ of occupations in creative activities were concentrated in São Paulo, $12.2 \%$ in Rio de Janeiro and $8.9 \%$ in Minas Gerais. In terms of the relative share of the Southeast in creative activities, the most important activities were those of Film, video production and television shows, sound recording and music (with 60.9\% of occupations in the region), Publishing and printing (60.3\%), Advertising agencies (60.3\%) and Information Technology and Services (59.8\%). On the other hand, $16.1 \%$ of the in creative activities were concentrated in the South, compared to $16.5 \%$ for the overall occupations, making the participation of creative activities in that region to reach to $1.9 \%$. In terms of distribution by the federative states in the region, $6.3 \%$ of occupations in creative activities were concentrated in Rio Grande do Sul, 5.7\% in Paraná and 4.0\% in Santa Catarina. In terms the relative share of the South, the most important activities were those of Publishing and printing (with 18.8\% of occupations in the region) and Information technology and services (17.2\%). The Northeast region concentrated $15.1 \%$ of occupations in creative activities, compared to $20.0 \%$ for the overall occupations, making the participation of creative activities in that region to reach to $1.2 \%$. In terms of distribution by federative states in the region, $4.2 \%$ of occupations in creative activities were concentrated in Bahia, 3.0\% in Pernambuco and $2.7 \%$ in Ceará. In terms of the relative share of the Northeast, the most important activities were those of Activities related to cultural heritage and environmental (with 24.6\% of occupations in the region), Artistic activities and spectacles (23.2\%) and Radio and television (18.2\%). The Midwest region concentrated $7.3 \%$ of occupations in creative activities, compared to $8.0 \%$ for the overall occupations, making the participation of creative activities in that region to reach to $1.8 \%$ In terms of distribution by federative states in the region, $2.6 \%$ of occupations in creative activities were concentrated in Goias and 2.4\% in the Federal District (Brasília). In terms of relative share of the Midwest, the most important activities were those of Radio and television (with $9.3 \%$ of occupations in the region) and Information technology and services (8.0\%). The North region concentrated $4.4 \%$ of occupations in creative activities, compared to $7.3 \%$ for the overall occupations, making the participation of creative activities in that region to reach to $2 \%$. In terms of distribution by federative states in the region, $1.8 \%$ of occupations in creative activities were concentrated in Pará and $1.2 \%$ in Amazonas. In 
terms of relative share of the North, the most important activities were those of Radio and television (with 8.1\% of occupations in the region) and Activities related to cultural heritage and environmental (7.8\%).

Another source of data comprises information about formal jobs in creative activities in 2013 extracted from RAIS, an annual survey about the conditions of the labor market conducted by the Brazilian Ministry of Labor. This information includes the total number of jobs, the overall amount of remuneration, the number of establishments and the average monthly salaries of employees in creative activities. According to data from RAIS, approximately 683.000 formal jobs were concentrated in creative activities in 2013 (Table 6), which accounted for 1.4\% of the overall formal employments recorded by RAIS (approximately 49 million in 2013). Considering the classification of economic activities of RAIS, the largest share were concentrated on Software development (with 326.438 formal jobs, equivalent to $47.8 \%$ of the overall jobs in creative activities), followed by Radio and TV (with 112.820 formal jobs, equivalent to $16.5 \%$ of the overall jobs in creative activities), Publishing and Printing (with 105.744, equivalent to $15.5 \%$ of the overall jobs in creative activities), Advertising agencies (with 31.574 formal jobs, equivalent to $4.6 \%$ of the overall jobs in creative activities) and Film, video and music (with 29.921 formal jobs, equivalent to $4.4 \%$ of the overall jobs in creative activities).

With regard to the regional distribution, according to data from RAIS, $61.3 \%$ of formal jobs in creative activities were concentrated in the Southeast, compared to $50.3 \%$ for the overall formal jobs, making the participation of creative activities in that region to reach to $1.7 \%$. In terms of distribution by federative states in that region, $40.4 \%$ of formal jobs in creative activities were concentrated in São Paulo, $11.6 \%$ in Rio de Janeiro and $7.6 \%$ in Minas Gerais. In terms of relative share of the Southeast, the most significant activities were the Design and interior decoration (with $67.2 \%$ of the formal jobs in the region) Software development (65.5\%) and Advertising agencies (65.1\%). the South region concentrated $17.2 \%$ of formal jobs in creative activities, corresponding to same percentage for the overall formal jobs, making the participation of creative activities in that region to reach to $1.4 \%$. In terms of distribution by federative states in the region, $6.7 \%$ of formal jobs in creative activities were concentrated in Rio Grande do Sul, 6.0\%, in Paraná and $4.6 \%$ in Santa Catarina. In terms of the South relative share, the most important activities were those of Photographic and similar activities (with 22.0\% of formal jobs in the region), Publishing and Printing (21.7\%) and Activities related to cultural heritage (21.2\%). The Northeast region concentrated $10.8 \%$ of formal jobs in creative activities, compared to $18.2 \%$ for the overall formal jobs, making the participation of creative activities in that region to reach to $0.8 \%$. In terms of distribution by federative states in that region, $2.6 \%$ of formal jobs in creative activities were concentrated in Bahia, 2.4\% in Ceará and 2.4\% in Pernambuco. In terms of the relative participation of the Northeast, the most important activities were those of Performing activities (with 20.9\% of formal jobs in the region), Activities of membership organizations linked to culture and art (20.3\%), Architectural services (14.8\%) and Activities related to cultural heritage (14.5\%). The Midwest region concentrated $8.0 \%$ of formal jobs in creative activities, compared to $8.7 \%$ for the overall formal jobs, making the participation of creative activities in that region to reach to $1.3 \%$. In terms of distribution by federative states in that region, $4.2 \%$ of formal jobs in creative activities were concentrated in the Federal District and $1.9 \%$ in Goiás. In terms of the relative share of the Midwest, the most significant activities were the Software development (with 9.0\% of formal jobs in the region), Radio and TV (8.9\%) and Film, video and music (8.1\%). The North region concentrated $2.7 \%$ of formal jobs in creative activities, compared to $5.6 \%$ for the overall formal jobs, making the participation of creative activities in that region to reach to $0.7 \%$. In terms of distribution by federative states in that region, $1.0 \%$ of formal jobs in creative activities were concentrated in Pará and $0.8 \%$ in the Amazonas. In terms of relative share of the North, the most important activities were those of Activities related to cultural heritage (with $8.8 \%$ of formal jobs in the region) Performing activities (6.3\%), Radio and TV (5.7\%) and Film, video and music (4.8\%). 
Table 5 - Creative Activities in General Demographic Census (2010) - sectoral and regional distribution of jobs in creative activities

\begin{tabular}{|c|c|c|c|c|c|c|c|c|c|c|c|}
\hline & Total & $\begin{array}{l}\text { Publishing and } \\
\text { printing }\end{array}$ & $\begin{array}{l}\text { Film, video } \\
\text { production and } \\
\text { television shows, } \\
\text { sound recording } \\
\text { and music }\end{array}$ & $\begin{array}{l}\text { Radio and } \\
\text { television }\end{array}$ & $\begin{array}{l}\text { Information } \\
\text { technology and } \\
\text { services }\end{array}$ & $\begin{array}{c}\text { Architectural } \\
\text { and engineering } \\
\text { activities and } \\
\text { related technical, } \\
\text { testis and } \\
\text { analysis }\end{array}$ & $\begin{array}{c}\text { Advertising } \\
\text { agencies }\end{array}$ & $\begin{array}{l}\text { Artistic } \\
\text { activities, } \\
\text { creative and } \\
\text { spectacles }\end{array}$ & $\begin{array}{l}\text { Activities related } \\
\text { to cultural } \\
\text { heritage and } \\
\text { environmental }\end{array}$ & $\begin{array}{l}\text { Sub-total } \\
\text { creative } \\
\text { activities }\end{array}$ & $\begin{array}{c}\text { Creative } \\
\text { activities /total }\end{array}$ \\
\hline Rondônia & $0,85 \%$ & $0,46 \%$ & \begin{tabular}{|r|}
$0,46 \%$ \\
\end{tabular} & $0,93 \%$ & $0,48 \%$ & \begin{tabular}{|r|}
$0,54 \%$ \\
\end{tabular} & $0,34 \%$ & $0,28 \%$ & $1,03 \%$ & $0,48 \%$ & $1,1 \%$ \\
\hline Acre & $0,32 \%$ & $0,08 \%$ & $0,29 \%$ & $0,52 \%$ & $0,11 \%$ & $0,43 \%$ & $0,07 \%$ & $0,16 \%$ & $0,35 \%$ & $0,22 \%$ & $1,3 \%$ \\
\hline Amazonas & $1,53 \%$ & $0,84 \%$ & $1,59 \%$ & $1,53 \%$ & $0,85 \%$ & $1,46 \%$ & $1,02 \%$ & $1,41 \%$ & $1,48 \%$ & $1,17 \%$ & $1,5 \%$ \\
\hline Roraima & $0,21 \%$ & $0,10 \%$ & $0,06 \%$ & $0,25 \%$ & $0,07 \%$ & $0,12 \%$ & $0,11 \%$ & $0,11 \%$ & $0,39 \%$ & $0,11 \%$ & $1,1 \%$ \\
\hline Pará & $3,36 \%$ & $1,04 \%$ & $1,79 \%$ & $3,26 \%$ & $1,15 \%$ & $1,98 \%$ & $1,50 \%$ & $2,49 \%$ & $3,21 \%$ & $1,79 \%$ & $1,0 \%$ \\
\hline Amapá & $0,30 \%$ & $0,21 \%$ & $0,13 \%$ & $0,72 \%$ & $0,11 \%$ & $0,11 \%$ & $0,10 \%$ & $0,22 \%$ & $0,53 \%$ & $0,18 \%$ & $1,2 \%$ \\
\hline Tocantins & $0,68 \%$ & $0,21 \%$ & $0,58 \%$ & $0,87 \%$ & $0,21 \%$ & $0,75 \%$ & $0,34 \%$ & $0,56 \%$ & $0,77 \%$ & $0,47 \%$ & $1,3 \%$ \\
\hline North & $7,25 \%$ & $2,93 \%$ & $4,91 \%$ & $8,07 \%$ & $2,98 \%$ & $5,41 \%$ & $3,48 \%$ & $5,23 \%$ & $7,75 \%$ & $4,43 \%$ & $1,2 \%$ \\
\hline Maranhão & $2,73 \%$ & $0,83 \%$ & $1,14 \%$ & $2,29 \%$ & $0,78 \%$ & $1,41 \%$ & $1,09 \%$ & $1,70 \%$ & $2,12 \%$ & $1,25 \%$ & $0,9 \%$ \\
\hline Piaúí & $1,41 \%$ & $0,54 \%$ & $0,35 \%$ & $1,70 \%$ & $0,53 \%$ & $0,39 \%$ & $0,87 \%$ & $1,21 \%$ & $1,64 \%$ & $0,76 \%$ & $1,0 \%$ \\
\hline Ceará & $3,89 \%$ & $2,01 \%$ & $2,05 \%$ & $2,78 \%$ & $2,42 \%$ & $2,24 \%$ & $2,29 \%$ & $4,38 \%$ & $3,96 \%$ & $2,73 \%$ & $1,4 \%$ \\
\hline Rio Grande do Norte & $1,43 \%$ & $0,75 \%$ & $1,07 \%$ & $1,00 \%$ & $0,79 \%$ & $0,82 \%$ & $0,79 \%$ & $1,74 \%$ & $1,82 \%$ & $1,00 \%$ & $1,4 \%$ \\
\hline Paraíba & $1,71 \%$ & $0,76 \%$ & $1,27 \%$ & $1,57 \%$ & $0,76 \%$ & $0,42 \%$ & $0,74 \%$ & $1,55 \%$ & $1,96 \%$ & $0,91 \%$ & $1,0 \%$ \\
\hline Pernambuco & $3,94 \%$ & $2,53 \%$ & $2,54 \%$ & $2,50 \%$ & $2,62 \%$ & $3,30 \%$ & $2,47 \%$ & $3,91 \%$ & $4,12 \%$ & $2,99 \%$ & $1,5 \%$ \\
\hline Alagoas & $1,30 \%$ & $0,38 \%$ & $0,81 \%$ & $1,20 \%$ & $0,45 \%$ & $0,60 \%$ & $0,69 \%$ & $1,17 \%$ & $1,06 \%$ & $0,70 \%$ & $1,0 \%$ \\
\hline Sergipe & $0,96 \%$ & $0,62 \%$ & $0,36 \%$ & $0,82 \%$ & $0,38 \%$ & $0,40 \%$ & $0,28 \%$ & $1,00 \%$ & $0,67 \%$ & $0,53 \%$ & $1,1 \%$ \\
\hline Bahia & $6,76 \%$ & $2,09 \%$ & $3,19 \%$ & $4,32 \%$ & $3,31 \%$ & $4,41 \%$ & $3,64 \%$ & $6,57 \%$ & $7,24 \%$ & $4,24 \%$ & $1,2 \%$ \\
\hline Northeast & $24,15 \%$ & $10,50 \%$ & $12,78 \%$ & $18,18 \%$ & $12,04 \%$ & $13,98 \%$ & $12,86 \%$ & $23,22 \%$ & $24,58 \%$ & $15,10 \%$ & $1,2 \%$ \\
\hline Minas Gerais & $10,73 \%$ & $7,92 \%$ & $6,79 \%$ & $9,62 \%$ & $8,12 \%$ & $10,52 \%$ & $8,84 \%$ & $8,29 \%$ & $10,94 \%$ & $8,88 \%$ & $1,6 \%$ \\
\hline Espírito Santo & $1,96 \%$ & $1,09 \%$ & $1,35 \%$ & $1,32 \%$ & $1,42 \%$ & $2,63 \%$ & $1,85 \%$ & $1,49 \%$ & $1,96 \%$ & $1,74 \%$ & $1,7 \%$ \\
\hline Rio de Janeiro & $\mathbf{8 , 2 8} \%$ & $11,16 \%$ & $17,67 \%$ & $14,23 \%$ & $11,51 \%$ & $13,24 \%$ & $9,25 \%$ & $13,00 \%$ & $12,05 \%$ & $12,15 \%$ & $2,8 \%$ \\
\hline São Paulo & $23,16 \%$ & $40,17 \%$ & $35,10 \%$ & $23,54 \%$ & $38,79 \%$ & $32,62 \%$ & $40,41 \%$ & $27,71 \%$ & $21,62 \%$ & $34,40 \%$ & $2,9 \%$ \\
\hline Southeast & $44,13 \%$ & $60,33 \%$ & $60,90 \%$ & $48,71 \%$ & $59,84 \%$ & $59,02 \%$ & $60,35 \%$ & $50,48 \%$ & $46,56 \%$ & $57,17 \%$ & $2,5 \%$ \\
\hline Paraná & $6,15 \%$ & $6,67 \%$ & $5,12 \%$ & $5,55 \%$ & $6,17 \%$ & $5,75 \%$ & $6,07 \%$ & $4,50 \%$ & $5,49 \%$ & $5,73 \%$ & $1,8 \%$ \\
\hline Santa Catarina & $3,95 \%$ & $3,80 \%$ & $2,94 \%$ & $3,55 \%$ & $4,75 \%$ & $3,83 \%$ & $3,97 \%$ & $3,50 \%$ & $2,80 \%$ & $4,01 \%$ & $2,0 \%$ \\
\hline Rio Grande do Sul & $6,41 \%$ & $8,30 \%$ & $5,87 \%$ & $6,69 \%$ & $6,24 \%$ & $5,68 \%$ & $6,43 \%$ & $6,45 \%$ & $5,64 \%$ & $6,31 \%$ & $1,9 \%$ \\
\hline South & $16,50 \%$ & $18,77 \%$ & $13,94 \%$ & $15,79 \%$ & $17,17 \%$ & $15,26 \%$ & $16,48 \%$ & $14,45 \%$ & $13,92 \%$ & $16,05 \%$ & $1,9 \%$ \\
\hline Mato Grosso do Sul & $1,37 \%$ & $1,59 \%$ & $1,01 \%$ & $1,60 \%$ & $0,96 \%$ & $1,09 \%$ & $1,04 \%$ & $1,05 \%$ & $1,30 \%$ & $1,10 \%$ & $1,6 \%$ \\
\hline Mato Grosso & $1,68 \%$ & $1,22 \%$ & $1,30 \%$ & $2,40 \%$ & $1,11 \%$ & $0,98 \%$ & $0,90 \%$ & $0,76 \%$ & $1,06 \%$ & $1,08 \%$ & $1,3 \%$ \\
\hline Goiás & $3,43 \%$ & $2,18 \%$ & $2,44 \%$ & $2,88 \%$ & $2,40 \%$ & $2,78 \%$ & $2,65 \%$ & $2,87 \%$ & $2,77 \%$ & $2,62 \%$ & $1,5 \%$ \\
\hline Distrito Federal & $1,49 \%$ & $2,47 \%$ & $2,72 \%$ & $2,37 \%$ & $3,51 \%$ & $1,50 \%$ & $2,24 \%$ & $1,94 \%$ & $2,06 \%$ & $2,45 \%$ & $3,2 \%$ \\
\hline Midwest & $7,96 \%$ & $7,46 \%$ & $7,47 \%$ & $9,25 \%$ & $7,98 \%$ & $6,34 \%$ & $6,84 \%$ & $6,62 \%$ & $7,18 \%$ & $7,25 \%$ & $1,8 \%$ \\
\hline TOTAL & 86.353 .839 & 102.208 & 39.461 & 100.703 & 518.755 & 364.565 & 217.597 & 290.257 & 40.583 & 1.674 .129 & $1,9 \%$ \\
\hline$\%$ creative activities in total & $100,0 \%$ & $\mathbf{0 , 1 \%}$ & $0,0 \%$ & $\mathbf{0 , 1} \%$ & $0,6 \%$ & $\mathbf{0 , 4} \%$ & $\mathbf{0 , 3} \%$ & $\mathbf{0 , 3} \%$ & $0,0 \%$ & $1,9 \%$ & \\
\hline \% in creative activities & & $6,1 \%$ & $2,4 \%$ & $6,0 \%$ & $31,0 \%$ & $21,8 \%$ & $13,0 \%$ & $17,3 \%$ & $2,4 \%$ & $100,0 \%$ & \\
\hline
\end{tabular}

Source: Own elaboration based on data from Brazilian Census (2010) 
Table 6 - Creative Activities and Formal Jobs - sectoral and regional distribution of formal jobs in creative activities - Data from RAIS (2013)

\begin{tabular}{|c|c|c|c|c|c|c|c|c|c|c|c|c|c|c|}
\hline & Total & $\begin{array}{c}\text { Publishing } \\
\text { and Printing }\end{array}$ & $\begin{array}{c}\text { Film, video } \\
\text { and music }\end{array}$ & $\begin{array}{c}\text { Radio and } \\
\text { TV }\end{array}$ & $\begin{array}{c}\text { Software } \\
\text { developmen } \\
\mathrm{t}\end{array}$ & $\begin{array}{c}\text { Architectura } \\
\text { 1 services }\end{array}$ & $\begin{array}{c}\text { Advertising } \\
\text { agencies }\end{array}$ & $\begin{array}{l}\text { Design and } \\
\text { interior } \\
\text { decoration }\end{array}$ & $\begin{array}{l}\text { Photographi } \\
\text { c and } \\
\text { similar } \\
\text { activities } \\
\end{array}$ & $\begin{array}{c}\text { Performing } \\
\text { activities }\end{array}$ & $\begin{array}{c}\text { Activities } \\
\text { related to } \\
\text { cultural } \\
\text { heritage }\end{array}$ & \begin{tabular}{|c|}
$\begin{array}{c}\text { Activities of } \\
\text { membership } \\
\text { organization } \\
\text { s linked to } \\
\text { culture and } \\
\text { art }\end{array}$ \\
\end{tabular} & $\begin{array}{c}\text { Sub-total } \\
\text { creative } \\
\text { activities }\end{array}$ & $\begin{array}{c}\text { Creative } \\
\text { activities } \\
\text { /total } \\
\end{array}$ \\
\hline Rondônia & $\mathbf{0 , 8} \%$ & $0,4 \%$ & $0,9 \%$ & $1,0 \%$ & $\begin{array}{r}0,1 \% \\
\end{array}$ & \begin{tabular}{|l}
$0,1 \%$ \\
\end{tabular} & $0,2 \%$ & $0,4 \%$ & $0,5 \%$ & $0,3 \%$ & $0,4 \%$ & $0,0 \%$ & $0,3 \%$ & $0,6 \%$ \\
\hline $\begin{array}{l}\text { Acre } \\
\end{array}$ & $0,3 \%$ & $0,1 \%$ & $0,2 \%$ & $0,3 \%$ & $0,0 \%$ & $0,2 \%$ & $0,1 \%$ & $0,4 \%$ & $0,1 \%$ & $0,0 \%$ & $3,3 \%$ & $0,3 \%$ & $0,1 \%$ & $0,7 \%$ \\
\hline Amazonas & $1,3 \%$ & $0,9 \%$ & $1,5 \%$ & $1,6 \%$ & $0,3 \%$ & $1,6 \%$ & $1,0 \%$ & $0,2 \%$ & $0,1 \%$ & $4,3 \%$ & $0,3 \%$ & $0,2 \%$ & $0,8 \%$ & $0,9 \%$ \\
\hline Roraima & $0,2 \%$ & $0,1 \%$ & $0,2 \%$ & $0,3 \%$ & $0,0 \%$ & $0,0 \%$ & $0,1 \%$ & $0,0 \%$ & $0,1 \%$ & $0,0 \%$ & $0,2 \%$ & $0,0 \%$ & $0,1 \%$ & $0,7 \%$ \\
\hline Pará & $2,3 \%$ & $1,2 \%$ & $1,5 \%$ & $1,9 \%$ & $0,4 \%$ & $1,3 \%$ & $1,4 \%$ & $1,7 \%$ & $1,4 \%$ & $1,4 \%$ & $4,5 \%$ & $2,2 \%$ & $1,0 \%$ & $0,6 \%$ \\
\hline Amapá & $0,3 \%$ & $0,0 \%$ & $0,2 \%$ & $0,2 \%$ & $0,0 \%$ & $0,2 \%$ & $0,2 \%$ & $0,1 \%$ & $0,0 \%$ & $0,1 \%$ & $0,1 \%$ & $0,4 \%$ & $0,1 \%$ & $0,5 \%$ \\
\hline Tocantins & $0,5 \%$ & $0,2 \%$ & $0,4 \%$ & $0,4 \%$ & $0,1 \%$ & $0,2 \%$ & $0,1 \%$ & $0,3 \%$ & $0,4 \%$ & $0,1 \%$ & $0,0 \%$ & $0,1 \%$ & $0,2 \%$ & $0,5 \%$ \\
\hline North & $5,6 \%$ & $2,9 \%$ & $4,8 \%$ & $5,7 \%$ & $0,9 \%$ & $3,6 \%$ & $3,2 \%$ & $3,0 \%$ & $2,7 \%$ & $6,3 \%$ & $\mathbf{8 , 8} \%$ & $3,2 \%$ & $2,7 \%$ & $0,7 \%$ \\
\hline Maranhão & $1,5 \%$ & $0,5 \%$ & $1,2 \%$ & $1,5 \%$ & $0,2 \%$ & $1,6 \%$ & $1,0 \%$ & $1,2 \%$ & $0,4 \%$ & $0,5 \%$ & $1,1 \%$ & $0,3 \%$ & $0,6 \%$ & $0,5 \%$ \\
\hline Piauí & $0,9 \%$ & $0,4 \%$ & $0,5 \%$ & $0,7 \%$ & $0,1 \%$ & $1,6 \%$ & $0,6 \%$ & $0,2 \%$ & $0,5 \%$ & $0,4 \%$ & $4,1 \%$ & $3,4 \%$ & $0,4 \%$ & $0,7 \%$ \\
\hline Ceará & $3,1 \%$ & $2,4 \%$ & $2,4 \%$ & $2,2 \%$ & $2,1 \%$ & $2,4 \%$ & $1,8 \%$ & $2,4 \%$ & $2,0 \%$ & $2,7 \%$ & $0,2 \%$ & $11,0 \%$ & $2,4 \%$ & $1,1 \%$ \\
\hline Rio Grande do Norte & $1,3 \%$ & $0,6 \%$ & $1,7 \%$ & $1,2 \%$ & $0,6 \%$ & $1,2 \%$ & $0,9 \%$ & $0,8 \%$ & $0,8 \%$ & $2,1 \%$ & $1,6 \%$ & $0,6 \%$ & $\mathbf{0 , 8} \%$ & $0,9 \%$ \\
\hline Paraíba & $1,3 \%$ & $0,9 \%$ & $1,0 \%$ & $1,5 \%$ & $0,4 \%$ & $0,2 \%$ & $0,6 \%$ & $0,3 \%$ & $0,5 \%$ & $2,2 \%$ & $0,0 \%$ & $0,4 \%$ & $0,7 \%$ & $\mathbf{0 , 8 \%}$ \\
\hline Pernambuco & $3,6 \%$ & $2,8 \%$ & $2,7 \%$ & $2,3 \%$ & $2,2 \%$ & $2,1 \%$ & $3,0 \%$ & $1,0 \%$ & $3,3 \%$ & $3,8 \%$ & $2,3 \%$ & $1,5 \%$ & $2,4 \%$ & $0,9 \%$ \\
\hline Alagoas & $1,0 \%$ & $0,3 \%$ & $0,7 \%$ & $0,8 \%$ & $0,3 \%$ & $0,5 \%$ & $0,6 \%$ & $0,1 \%$ & $0,8 \%$ & $0,4 \%$ & $0,1 \%$ & $0,4 \%$ & $0,4 \%$ & $0,5 \%$ \\
\hline Sergipe & $\mathbf{0 , 8} \%$ & $0,5 \%$ & $0,5 \%$ & $0,7 \%$ & $0,2 \%$ & $1,4 \%$ & $0,9 \%$ & $0,1 \%$ & $0,6 \%$ & $0,9 \%$ & $0,2 \%$ & $0,3 \%$ & $0,4 \%$ & $0,7 \%$ \\
\hline Bahia & $4,7 \%$ & $1,8 \%$ & $2,9 \%$ & $2,9 \%$ & $2,2 \%$ & $3,9 \%$ & $3,4 \%$ & $3,6 \%$ & $2,9 \%$ & $8,0 \%$ & $4,9 \%$ & $2,4 \%$ & $2,6 \%$ & $\mathbf{0 , 8} \%$ \\
\hline Northeast & $18,2 \%$ & $10,2 \%$ & $13,6 \%$ & $13,6 \%$ & $8,2 \%$ & $14,8 \%$ & $12,8 \%$ & $9,7 \%$ & $11,8 \%$ & $20,9 \%$ & $14,5 \%$ & $20,3 \%$ & $10,8 \%$ & $0,8 \%$ \\
\hline Minas Gerais & $10,3 \%$ & $7,0 \%$ & $6,2 \%$ & $7,2 \%$ & $7,9 \%$ & $8,3 \%$ & $6,4 \%$ & $6,1 \%$ & $10,9 \%$ & $10,5 \%$ & $11,2 \%$ & $5,4 \%$ & $7,6 \%$ & $1,0 \%$ \\
\hline Espírito Santo & $2,0 \%$ & $1,9 \%$ & $1,2 \%$ & $1,9 \%$ & $1,5 \%$ & $1,4 \%$ & $1,5 \%$ & $1,4 \%$ & $2,2 \%$ & $0,9 \%$ & $0,3 \%$ & $2,9 \%$ & $1,6 \%$ & $1,2 \%$ \\
\hline Rio de Janeiro & $9,4 \%$ & $10,2 \%$ & $15,9 \%$ & $14,6 \%$ & $10,9 \%$ & $17,3 \%$ & $8,4 \%$ & $11,4 \%$ & $8,6 \%$ & $16,8 \%$ & $15,6 \%$ & $7,6 \%$ & $11,6 \%$ & $1,7 \%$ \\
\hline São Paulo & $28,7 \%$ & $40,5 \%$ & $37,0 \%$ & $29,8 \%$ & $45,2 \%$ & $33,0 \%$ & $48,9 \%$ & $48,3 \%$ & $35,2 \%$ & $24,1 \%$ & $23,5 \%$ & $42,8 \%$ & $40,4 \%$ & $2,0 \%$ \\
\hline Southeast & $50,3 \%$ & $59,6 \%$ & $60,4 \%$ & $53,4 \%$ & $65,5 \%$ & $59,9 \%$ & $65,1 \%$ & $67,2 \%$ & $56,9 \%$ & $52,3 \%$ & $50,6 \%$ & $58,7 \%$ & $61,3 \%$ & $1,7 \%$ \\
\hline Paraná & $6,4 \%$ & $8,6 \%$ & $5,0 \%$ & $5,7 \%$ & $5,5 \%$ & $4,1 \%$ & $3,7 \%$ & $6,4 \%$ & $6,8 \%$ & $5,5 \%$ & $14,7 \%$ & $6,2 \%$ & $6,0 \%$ & $1,3 \%$ \\
\hline $\begin{array}{l}\text { Santa Catarina } \\
\end{array}$ & $4,5 \%$ & $3,8 \%$ & $3,2 \%$ & $4,6 \%$ & $5,3 \%$ & $3,4 \%$ & $3,7 \%$ & $4,4 \%$ & $6,4 \%$ & $2,9 \%$ & $0,3 \%$ & $3,4 \%$ & $4,6 \%$ & $1,4 \%$ \\
\hline Rio Grande do Sul & $6,3 \%$ & $9,4 \%$ & $4,9 \%$ & $8,0 \%$ & $5,6 \%$ & 7,3\% & $4,5 \%$ & $3,0 \%$ & $8,8 \%$ & $4,5 \%$ & $6,1 \%$ & $3,8 \%$ & $6,5 \%$ & $1,4 \%$ \\
\hline South & $17,2 \%$ & $21,7 \%$ & $13,2 \%$ & $18,4 \%$ & $16,3 \%$ & $14,8 \%$ & $12,0 \%$ & $13,8 \%$ & $22,0 \%$ & $13,0 \%$ & $21,2 \%$ & $13,4 \%$ & $17,2 \%$ & $1,4 \%$ \\
\hline Mato Grosso do Sul & $1,3 \%$ & $1,0 \%$ & $1,1 \%$ & $1,4 \%$ & $0,8 \%$ & $1,0 \%$ & $1,1 \%$ & $0,3 \%$ & $0,7 \%$ & $1,9 \%$ & $0,9 \%$ & $0,6 \%$ & $1,0 \%$ & $1,1 \%$ \\
\hline Mato Grosso & $1,6 \%$ & $0,6 \%$ & $2,2 \%$ & $1,4 \%$ & $0,8 \%$ & $0,8 \%$ & $1,1 \%$ & $1,3 \%$ & $1,2 \%$ & $0,6 \%$ & $0,2 \%$ & $0,4 \%$ & $0,9 \%$ & $\mathbf{0 , 8 \%}$ \\
\hline Goiás & $3,1 \%$ & $1,9 \%$ & $2,3 \%$ & $2,6 \%$ & $1,7 \%$ & $2,6 \%$ & $1,5 \%$ & $2,6 \%$ & $2,4 \%$ & $3,0 \%$ & $0,9 \%$ & $0,9 \%$ & $1,9 \%$ & $0,9 \%$ \\
\hline Distrito Federal & $2,7 \%$ & $2,1 \%$ & $2,5 \%$ & $3,4 \%$ & $5,8 \%$ & $2,4 \%$ & $3,3 \%$ & $2,1 \%$ & $2,2 \%$ & $1,8 \%$ & $2,9 \%$ & $2,4 \%$ & $4,2 \%$ & $2,2 \%$ \\
\hline $\begin{array}{l}\text { Midwest } \\
\end{array}$ & $8,7 \%$ & $5,6 \%$ & $8,1 \%$ & $8,9 \%$ & $9,0 \%$ & $6,9 \%$ & $6,9 \%$ & $6,2 \%$ & $6,6 \%$ & $7,4 \%$ & $5,0 \%$ & $4,4 \%$ & $8,0 \%$ & $1,3 \%$ \\
\hline TOTAL & 48.948 .433 & 105.744 & 29.921 & 112.820 & 326.438 & 9.351 & 31.574 & 3.552 & 18.741 & 19.190 & 6.673 & 18.876 & 682.880 & $1,4 \%$ \\
\hline$\%$ creative activities in total & $100,0 \%$ & $\mathbf{0 , 2} \%$ & $0,1 \%$ & $0,2 \%$ & $\mathbf{0 , 7 \%}$ & $0,0 \%$ & $0,1 \%$ & $0,0 \%$ & $0,0 \%$ & $0,0 \%$ & $0,0 \%$ & $0,0 \%$ & $1,4 \%$ & \\
\hline \% in creative activities & & $15,5 \%$ & $4,4 \%$ & $16,5 \%$ & $47,8 \%$ & $1,4 \%$ & $4,6 \%$ & $0,5 \%$ & $2,7 \%$ & $2,8 \%$ & $1,0 \%$ & $2,8 \%$ & $100,0 \%$ & \\
\hline
\end{tabular}

Source: Own elaboration based on data from RAIS (2013) 
Table 7 - Index of formalization in labor market - formal jobs extracted from RAIS compared to total occupations extracted from Demographic

\begin{tabular}{|c|c|c|c|c|c|c|c|c|c|c|c|}
\hline \multicolumn{12}{|c|}{ Census) - 2010} \\
\hline & Total & $\begin{array}{c}\text { Publishing and } \\
\text { printing }\end{array}$ & \begin{tabular}{|c|} 
Film, video \\
production and \\
television shows, \\
sound recording \\
and music \\
\end{tabular} & $\begin{array}{l}\text { Radio and } \\
\text { television }\end{array}$ & $\begin{array}{c}\text { Information } \\
\text { technology and } \\
\text { services }\end{array}$ & $\begin{array}{l}\text { Architectural and } \\
\text { engineering } \\
\text { activities and } \\
\text { related technical, } \\
\text { tests and analysis } \\
\end{array}$ & $\begin{array}{l}\text { Advertising } \\
\text { agencies }\end{array}$ & $\begin{array}{l}\text { Artistic } \\
\text { activities, } \\
\text { creative and } \\
\text { spectacles } \\
\end{array}$ & $\begin{array}{c}\text { Activities related } \\
\text { to cultural } \\
\text { heritage and } \\
\text { environmental } \\
\end{array}$ & $\begin{array}{l}\text { Sub-total } \\
\text { creative } \\
\text { activities }\end{array}$ & $\begin{array}{c}\text { Crative } \\
\text { activities /total } \\
\end{array}$ \\
\hline Rondônia & $45,7 \%$ & $96,8 \%$ & \begin{tabular}{|l|}
$119,3 \%$ \\
\end{tabular} & $105,0 \%$ & $6,2 \%$ & $\begin{array}{r}1,2 \% \\
\end{array}$ & $22,5 \%$ & $4,0 \%$ & $7,9 \%$ & $25,7 \%$ & $56,2 \%$ \\
\hline $\begin{array}{l}\text { Acre } \\
\end{array}$ & $43,4 \%$ & $107,5 \%$ & $27,6 \%$ & $52,4 \%$ & $8,9 \%$ & $2,0 \%$ & $37,2 \%$ & $1,3 \%$ & $241,8 \%$ & $24,2 \%$ & $55,7 \%$ \\
\hline Amazonas & $43,5 \%$ & $109,3 \%$ & $54,9 \%$ & $94,0 \%$ & $14,5 \%$ & $4,9 \%$ & $19,7 \%$ & $3,7 \%$ & $81,3 \%$ & $23,9 \%$ & $55,0 \%$ \\
\hline Roraima & $43,3 \%$ & $125,5 \%$ & $144,0 \%$ & $103,2 \%$ & $11,4 \%$ & $0,0 \%$ & $30,5 \%$ & $4,5 \%$ & $9,5 \%$ & $29,5 \%$ & $68,1 \%$ \\
\hline Pará & $32,8 \%$ & $119,2 \%$ & $43,6 \%$ & $60,7 \%$ & $32,9 \%$ & $2,6 \%$ & $20,1 \%$ & $2,3 \%$ & $72,3 \%$ & $24,9 \%$ & $76,0 \%$ \\
\hline Amapá & $41,5 \%$ & $9,5 \%$ & $105,7 \%$ & $31,6 \%$ & $5,6 \%$ & $0,7 \%$ & $37,7 \%$ & $3,0 \%$ & $0,0 \%$ & $14,4 \%$ & $34,8 \%$ \\
\hline Tocantins & $40,9 \%$ & $97,7 \%$ & $17,0 \%$ & $31,6 \%$ & $13,3 \%$ & $2,1 \%$ & $20,6 \%$ & $1,9 \%$ & $3,2 \%$ & $11,8 \%$ & $28,8 \%$ \\
\hline North & $38,5 \%$ & $103,4 \%$ & $53,3 \%$ & $67,2 \%$ & $19,6 \%$ & $2,9 \%$ & $21,4 \%$ & $2,8 \%$ & $58,1 \%$ & $23,0 \%$ & $59,8 \%$ \\
\hline Maranhão & $27,0 \%$ & $58,9 \%$ & $59,7 \%$ & $57,5 \%$ & $12,4 \%$ & $1,8 \%$ & $13,4 \%$ & $1,3 \%$ & $8,8 \%$ & $15,0 \%$ & $55,6 \%$ \\
\hline Piaúí & $31,1 \%$ & $84,6 \%$ & $56,1 \%$ & $34,9 \%$ & $6,2 \%$ & $4,1 \%$ & $10,7 \%$ & $0,9 \%$ & $85,2 \%$ & $17,1 \%$ & $55,2 \%$ \\
\hline Ceará & $39,4 \%$ & $137,3 \%$ & $81,2 \%$ & $83,6 \%$ & $36,1 \%$ & $3,7 \%$ & $17,8 \%$ & $3,1 \%$ & $93,0 \%$ & $29,4 \%$ & $74,6 \%$ \\
\hline Rio Grande do Norte & $46,4 \%$ & $103,3 \%$ & $59,8 \%$ & $113,2 \%$ & $13,3 \%$ & $5,8 \%$ & $24,9 \%$ & $6,5 \%$ & $25,8 \%$ & $23,0 \%$ & $49,5 \%$ \\
\hline Paraíba & $39,2 \%$ & $172,0 \%$ & $38,1 \%$ & $100,9 \%$ & $29,1 \%$ & $2,8 \%$ & $17,8 \%$ & $8,7 \%$ & $9,7 \%$ & $33,4 \%$ & $85,1 \%$ \\
\hline Pernambuco & $45,1 \%$ & $89,9 \%$ & $51,2 \%$ & $77,9 \%$ & $33,5 \%$ & $11,2 \%$ & $21,9 \%$ & $4,3 \%$ & $56,7 \%$ & $26,5 \%$ & $58,8 \%$ \\
\hline Alagoas & $42,0 \%$ & $137,7 \%$ & $35,9 \%$ & $69,1 \%$ & $26,8 \%$ & $2,3 \%$ & $13,0 \%$ & $1,5 \%$ & $22,1 \%$ & $21,3 \%$ & $50,8 \%$ \\
\hline Sergipe & $44,4 \%$ & $98,7 \%$ & $83,7 \%$ & $93,5 \%$ & $34,6 \%$ & $3,2 \%$ & $39,1 \%$ & $4,3 \%$ & $14,3 \%$ & $30,0 \%$ & $67,7 \%$ \\
\hline Bahia & $36,6 \%$ & $108,9 \%$ & $55,8 \%$ & $66,7 \%$ & $42,4 \%$ & $3,5 \%$ & $23,0 \%$ & $5,3 \%$ & $25,9 \%$ & $24,5 \%$ & $66,9 \%$ \\
\hline Northeast & $38,4 \%$ & $109,2 \%$ & $57,4 \%$ & $73,6 \%$ & $32,1 \%$ & $5,2 \%$ & $19,8 \%$ & $4,3 \%$ & $42,6 \%$ & $25,1 \%$ & $65,4 \%$ \\
\hline Minas Gerais & $50,2 \%$ & $103,9 \%$ & $63,1 \%$ & $82,2 \%$ & $48,9 \%$ & $5,0 \%$ & $17,8 \%$ & $7,7 \%$ & $40,2 \%$ & $32,0 \%$ & $63,8 \%$ \\
\hline Espírito Santo & $50,8 \%$ & $174,6 \%$ & $48,4 \%$ & $146,0 \%$ & $56,5 \%$ & $2,8 \%$ & $18,4 \%$ & $4,1 \%$ & $24,9 \%$ & $33,3 \%$ & $65,7 \%$ \\
\hline Rio de Janeiro & $57,1 \%$ & $106,0 \%$ & $57,6 \%$ & $124,8 \%$ & $47,4 \%$ & $3,6 \%$ & $20,5 \%$ & $8,8 \%$ & $62,4 \%$ & $36,6 \%$ & $64,2 \%$ \\
\hline São Paulo & $64,4 \%$ & $114,8 \%$ & $66,6 \%$ & $139,3 \%$ & $59,2 \%$ & $4,3 \%$ & $25,5 \%$ & $4,6 \%$ & $88,4 \%$ & $43,0 \%$ & $66,8 \%$ \\
\hline Southeast & $58,9 \%$ & $112,8 \%$ & $63,2 \%$ & $124,0 \%$ & $55,4 \%$ & $4,2 \%$ & $23,4 \%$ & $6,2 \%$ & $67,7 \%$ & $39,6 \%$ & $67,3 \%$ \\
\hline Paraná & $52,4 \%$ & $137,2 \%$ & $65,3 \%$ & $101,6 \%$ & $33,2 \%$ & $2,3 \%$ & $20,2 \%$ & $5,7 \%$ & $119,4 \%$ & $35,0 \%$ & $66,6 \%$ \\
\hline Santa Catarina & $57,8 \%$ & $114,6 \%$ & $79,3 \%$ & $130,6 \%$ & $51,0 \%$ & $3,7 \%$ & $24,9 \%$ & $6,2 \%$ & $61,6 \%$ & $39,6 \%$ & $68,6 \%$ \\
\hline Rio Grande do Sul & $50,7 \%$ & $130,0 \%$ & $58,6 \%$ & $133,4 \%$ & $34,3 \%$ & $2,5 \%$ & $20,0 \%$ & $4,1 \%$ & $41,8 \%$ & $35,5 \%$ & $70,1 \%$ \\
\hline South & $53,0 \%$ & $129,4 \%$ & $65,4 \%$ & $121,6 \%$ & $38,5 \%$ & $2,7 \%$ & $21,3 \%$ & $5,1 \%$ & $76,4 \%$ & $36,3 \%$ & $68,5 \%$ \\
\hline Mato Grosso do Sul & $47,5 \%$ & $55,4 \%$ & $76,3 \%$ & $90,7 \%$ & $40,2 \%$ & $2,4 \%$ & $21,2 \%$ & $8,9 \%$ & $33,5 \%$ & $30,9 \%$ & $65,0 \%$ \\
\hline Mato Grosso & $45,3 \%$ & $63,9 \%$ & $72,2 \%$ & $59,5 \%$ & $13,7 \%$ & $2,6 \%$ & $26,4 \%$ & $3,9 \%$ & $17,4 \%$ & $23,0 \%$ & $50,8 \%$ \\
\hline Goiás & $44,4 \%$ & $89,6 \%$ & $46,1 \%$ & $90,2 \%$ & $54,8 \%$ & $2,2 \%$ & $13,7 \%$ & $3,6 \%$ & $22,4 \%$ & $30,6 \%$ & $69,0 \%$ \\
\hline Distrito Federal & $85,4 \%$ & $78,7 \%$ & $64,5 \%$ & $150,6 \%$ & $92,2 \%$ & $4,5 \%$ & $31,2 \%$ & $5,6 \%$ & $79,8 \%$ & $63,0 \%$ & $73,7 \%$ \\
\hline Midwest & $52,8 \%$ & $74,5 \%$ & $61,4 \%$ & $97,8 \%$ & $63,8 \%$ & $2,8 \%$ & $22,3 \%$ & $5,1 \%$ & $40,1 \%$ & $40,5 \%$ & $76,6 \%$ \\
\hline TOTAL & $51,0 \%$ & $112,4 \%$ & $62,2 \%$ & $107,4 \%$ & $49,3 \%$ & $4,0 \%$ & $22,4 \%$ & $5,3 \%$ & $60,0 \%$ & $36,2 \%$ & $71,0 \%$ \\
\hline
\end{tabular}

Source: Own elaboration based on data from Brazilian Census (2010) and RAIS (2010) 
A subsequent analysis comprises an effort to match the information about the distribution of jobs in creative activities extracted from RAIS and from the Census. The data from Census comprises a classification of activities in which the respondents were employed, while the data from RAIS refers to the classification of the sector of activity of the respondent companies. Matching those data, through a harmonization of the classification of activities, we tried to define an index of "formalization" of the labor market in creative activities, given by the relationship among the data (Table 7). According to the information collected for the set of creative activities, this ratio reached $36.2 \%$ in 2010 , which is $29 \%$ lower than the ratio observed for the overall activities (51.0\%), reflecting the lower level of formal employment in creative activities. However, the "index of formalization" of employment showed particularly high values (above 100\%) in some sectors, such as Publishing and printing and Radio and television. Probably, these high rates occurred because of the criteria applied to identify the correspondent activities in each source of data. In contrast, this index had significantly lower values for other sectors, such as Architectural and engineering activities and related analyzes, Artistic activities and spectacles and Advertising agencies. In most of these activities, the low degree of formalization can be explained by the presence of self-employed workers. Regionally, the "index of formalization" of the labor market in creative activities was highest in the Midwest region, reaching $40.5 \%$ because of the value observed in the Federal District (63.0\%). In the Southeast, this index reached 39.6\%, reflecting the high value observed in São Paulo (43.0\%). In the South, the index reached 36.3\%, reflecting the high value observed in Santa Catarina (39.6\%). Contrastingly, the index presented significantly lower values in the North (23.0\%) and in the Northeast (25.1\%).

\section{2 - Salaries}

The RAIS database also provides information about the amount of monthly salaries paid in creative activities. According to data from RAIS, approximately $2.2 \%$ of the overall monthly remuneration was concentrated in creative activities, totaling approximately R\$ 2.2 billion per month in 2013 (Table 8). Of this total, the largest share was concentrated on Software development (with 55.8\% of the monthly remuneration in creative activities), followed by Radio and TV (17.2\%), Publishing and Printing (13.1\%), Advertising agencies (5.2\%) and Film, video and music (2.4\%).

With regard to regional distribution of salaries, according to data from RAIS, $71.3 \%$ of the monthly remuneration in creative activities was concentrated in the Southeast, against 53.8\% for the overall monthly salaries, making the participation of creative activities in that region to rise to $2.9 \%$. In terms of distribution by federative states in the region, $49.3 \%$ of the monthly remuneration for creative activities were concentrated in São Paulo, $14.8 \%$ in Rio de Janeiro and 5.9\% in Minas Gerais. In terms of the relative share of the Southeast, the most important activities were those of Advertising agencies (with $80.9 \%$ of the monthly remuneration concentrated in that region) Software development (72.4\%), Film, video and music (72.6\%) and Architectural services (71.2\%). Among the other regions, $13.2 \%$ of the monthly remunerations in creative activities were concentrated in the South, compared to $16.0 \%$ for the overall monthly salaries, making the participation of creative activities in that region to reach to $1.8 \%$. In terms of the distribution by federative states in the region, $5.3 \%$ of the monthly remunerations in creative activities were concentrated in Rio Grande do Sul, 4.4\% in Paraná and 3.5\% in Santa Catarina. In terms of the relative share of the South, the most important activities were those of Photographic and similar activities (with $21.3 \%$ of the monthly remuneration concentrated in that region), Design and Interior decoration (16.5\%) and Publishing and Printing (16.4\%). The Midwest region concentrated 7.5\% of the monthly remunerations in creative activities, compared to $10.2 \%$ for the overall monthly salaries, making the participation of creative activities in that region to reach to $1.6 \%$. In terms of the distribution by federative states in the region, 5.2\% of monthly remunerations in creative activities were concentrated in the Federal District (Brasília) and 1.1\% in Goiás. In terms of the relative share of the Midwest, the most important activities were those of Radio and TV (with $8.7 \%$ of the monthly remuneration concentrated in that region) Software development (8.3\%), and Performing activities (6.0\%). The Northeast region concentrated $6.5 \%$ of the monthly remunerations in creative activities, compared to $14.6 \%$ for the overall monthly salaries, making the participation of creative activities in that region to reach to $1.0 \%$. In terms of 
distribution by federative states in the region, $1.8 \%$ of the monthly remuneration in creative activities were concentrated in Pernambuco, 1.6\% in Bahia and 1.4\% in Ceará. In terms of the relative participation of the Northeast, the most important activities were those of Performing activities (with 16.3\% of the monthly remuneration concentrated in that region), Activities of membership organizations linked to culture and arts (15.9\%), Architectural services (11.6\%), Radio and TV (8.7\%), and Film, video and music (8.3\%). The North region concentrated $1.6 \%$ of the monthly remunerations in creative activities, compared to $5.3 \%$ for the overall monthly salaries, making the participation of creative activities in that region to reach to $0.6 \%$. In terms of distribution by federative states in the region, $0.7 \%$ of the monthly remuneration for creative activities were concentrated in Pará and 0.5\% in the Amazonas. In terms of the relative share of the North, the most important activities were those of Activities related to cultural heritage (with $15.1 \%$ of the monthly remuneration concentrated in that region) and Performing activities (6.9\%).

Based on the classification of economic activities used by RAIS, we can also analyze the distribution of the average monthly remuneration of workers involved in creative activities in 2013 (Table 9). For the set of sectors characterized as creative activities, the monthly average salary reached $\mathrm{R} \$ 3.216$ in 2013, corresponding to a value $55.1 \%$ higher than the overall monthly average salary accounted by RAIS ( $\mathrm{R} \$ 2.073$ ). Among the creative activities considered, this salary was highest in Software development (R\$ 3.751), Advertising agencies (R\$ 3.636), Radio and TV (R\$ 3.356) and Activities related to cultural heritage ( $\mathrm{R} \$ 3.302)$. In contrast, among the selected activities, those with lower average monthly salaries were the Activities of membership organizations linked to culture and arts (R\$1.694) and Photographic and similar activities (R\$1.190).

Concerning the regional distribution, a higher monthly salary ( $\mathrm{R} \$ 3.738$ ) was observed in the Southeast, where we can also observed a high positive differential between the remuneration in creative activities and in the overall activities, which reached 68.4\%. This trend also occurred in the Midwest, where the remuneration in creative activities reached $\mathrm{R} \$ 3.004$, a figure $23.2 \%$ higher than in the overall activities in the region. In the South, the remuneration in creative activities reached $\mathrm{R} \$ 2.472$, a figure $28.0 \%$ higher than in the overall activities. In the Northeast, these values reached R\$ 1.923 and $15.6 \%$, respectively. Contrasting to the other regions, in the North the remuneration generated in creative activities reached $\mathrm{R} \$ 1.888$, a figure $4.1 \%$ lower than that observed in the overall activities.

Among the selected activities, higher average monthly salaries were observed in the case of Radio and TV, in Rio de Janeiro ( $\mathrm{R}$ \$ 6.703) and in the Federal District ( $\mathrm{R}$ \$ 5.336). In Advertising agencies, higher salaries levels were observed in São Paulo (R\$ 5.096). In Software development, higher salaries were observed in São Paulo (R \$ 4.422) and in the Federal District (R\$ 4.146). In contrast, those salaries were particularly low for the sectors of Design and Interior decoration and for Photographic and similar activities in the Northeast and in the North. In the Northeast, the salaries paid in Design and Interior decoration reached $\mathrm{R} \$ 1.284$, while in the Photographic and similar activities they reached $\mathrm{R} \$ 854$. In the North region, the salaries paid in the sector of Design and Interior decoration reached R\$ 958 while in the Photographic and similar activities they reached R\$ 914.

From the data extracted from RAIS, we can compare the dynamics of selected creative activities in the period 2006-2013 with the performance of the overall activities. In terms of total employment, creative activities showed a $51 \%$ growth in that period, compared to a $39 \%$ growth for the overall activities (Table 10). Among the different creative activities, those that had a higher employment growth were the Software Development (106\%), Design and Interior decoration (91\%), Performing activities (63\%) and Organizations linked to culture and art (52\%). Concerning the amount of remunerations, creative activities increased by $166 \%$ in that period, compared to a growth of $147 \%$ for the overall activities reported by RAIS. Among the various creative activities, those that had a higher growth of the amount of remunerations was the Design and interior decoration (381\%) Software development (254\%) and Performing activities (192\%). Finally, as regards the average monthly salaries, creative activities grew by $76.5 \%$ in that period, compared to a growth of $77.3 \%$ to the overall activities. Among creative activities, those that had a higher growth of average monthly salaries were the Design and Interior Decoration (152.2\%), Activities related to cultural heritage (99.9\%), Advertising agencies (98.9\%) and Performing activities (78.4\%). 
Table 8 - Creative Activities and Income Generation - Monthly Labor Income (R\$) in formal jobs - Data from RAIS (2013) - RS 1000

\begin{tabular}{|c|c|c|c|c|c|c|c|c|c|c|c|c|c|c|}
\hline & Total & $\begin{array}{c}\text { Publishing } \\
\text { and Printing }\end{array}$ & $\begin{array}{l}\text { Film, video } \\
\text { and music }\end{array}$ & $\begin{array}{l}\text { Radio and } \\
\text { TV } \\
\end{array}$ & $\begin{array}{c}\text { Software } \\
\text { developmen } \\
\mathrm{t}\end{array}$ & $\begin{array}{c}\text { Architectura } \\
\text { l services } \\
\end{array}$ & $\begin{array}{c}\text { Advertising } \\
\text { agencies }\end{array}$ & $\begin{array}{c}\text { Design and } \\
\text { interior } \\
\text { decoration } \\
\end{array}$ & $\begin{array}{c}\text { Photographi } \\
\text { c and } \\
\text { similar } \\
\text { activities } \\
\end{array}$ & $\begin{array}{c}\text { Performing } \\
\text { activities }\end{array}$ & $\begin{array}{l}\text { Activities } \\
\text { related to } \\
\text { cultural } \\
\text { heritage }\end{array}$ & $\begin{array}{c}\text { Activities of } \\
\text { membership } \\
\text { organization } \\
\text { s linked to } \\
\text { culture and } \\
\text { art } \\
\end{array}$ & $\begin{array}{c}\text { Sub-total } \\
\text { creative } \\
\text { activities } \\
\end{array}$ & $\begin{array}{c}\text { Creative } \\
\text { activities } \\
\text { /total } \\
\end{array}$ \\
\hline Rondônia & $0,7 \%$ & $0,2 \%$ & $0,6 \%$ & $0,5 \%$ & $\mathbf{0 , 0} \%$ & $0,0 \%$ & $0,1 \%$ & $0,2 \%$ & $0,3 \%$ & $0,2 \%$ & $0,2 \%$ & $\mathbf{0 , 0} \%$ & $0,1 \%$ & $0,5 \%$ \\
\hline Acre & $0,3 \%$ & $0,0 \%$ & $0,1 \%$ & $0,2 \%$ & $0,0 \%$ & $0,1 \%$ & $0,0 \%$ & $0,2 \%$ & $0,1 \%$ & $0,0 \%$ & $2,1 \%$ & $0,3 \%$ & $0,1 \%$ & $0,6 \%$ \\
\hline Amazonas & $1,3 \%$ & $0,7 \%$ & $0,9 \%$ & $1,1 \%$ & $0,1 \%$ & $1,2 \%$ & $0,6 \%$ & $\mathbf{0 , 1 \%}$ & $\mathbf{0 , 1 \%}$ & $5,7 \%$ & $0,1 \%$ & $0,2 \%$ & $0,5 \%$ & $0,9 \%$ \\
\hline Roraima & $0,2 \%$ & $0,0 \%$ & $0,1 \%$ & $0,2 \%$ & $0,0 \%$ & $\mathbf{0 , 0 \%}$ & $\mathbf{0 , 0 \%}$ & $\mathbf{0 , 0 \%}$ & $0,1 \%$ & $\mathbf{0 , 0 \%}$ & $0,1 \%$ & $0,0 \%$ & $0,0 \%$ & $0,5 \%$ \\
\hline Pará & $2,1 \%$ & $0,8 \%$ & $0,9 \%$ & $0,9 \%$ & $0,3 \%$ & $0,8 \%$ & $0,7 \%$ & $1,0 \%$ & $1,1 \%$ & $0,9 \%$ & $13,0 \%$ & $1,9 \%$ & $0,7 \%$ & $0,7 \%$ \\
\hline Amapá & $0,3 \%$ & $0,0 \%$ & $0,1 \%$ & $0,1 \%$ & $0,0 \%$ & $0,1 \%$ & $0,1 \%$ & $0,0 \%$ & $0,0 \%$ & $0,1 \%$ & $\mathbf{0 , 0} \%$ & $0,2 \%$ & $0,0 \%$ & $0,3 \%$ \\
\hline Tocantins & $0,5 \%$ & $0,1 \%$ & $0,2 \%$ & $0,2 \%$ & $\mathbf{0 , 0} \%$ & $0,1 \%$ & $0,1 \%$ & $0,1 \%$ & $0,3 \%$ & $0,1 \%$ & $\mathbf{0 , 0 \%}$ & $0,0 \%$ & $0,1 \%$ & $0,4 \%$ \\
\hline North & $5,3 \%$ & $1,8 \%$ & $3,1 \%$ & $3,1 \%$ & $0,5 \%$ & $2,3 \%$ & $1,5 \%$ & $1,7 \%$ & $2,1 \%$ & $6,9 \%$ & $15,5 \%$ & $2,7 \%$ & $1,6 \%$ & $0,6 \%$ \\
\hline Maranhão & $1,2 \%$ & $0,2 \%$ & $0,7 \%$ & $0,8 \%$ & $0,1 \%$ & $0,9 \%$ & $0,4 \%$ & $0,7 \%$ & $0,3 \%$ & $0,3 \%$ & $0,5 \%$ & $0,2 \%$ & $0,3 \%$ & $0,5 \%$ \\
\hline Piaú́ & $0,7 \%$ & $0,2 \%$ & $0,3 \%$ & $0,4 \%$ & $0,0 \%$ & $0,7 \%$ & $0,2 \%$ & $0,1 \%$ & $0,4 \%$ & $0,2 \%$ & $2,0 \%$ & $2,4 \%$ & $0,2 \%$ & $0,6 \%$ \\
\hline Ceará & $2,3 \%$ & $1,4 \%$ & $1,5 \%$ & $1,3 \%$ & $1,3 \%$ & $1,8 \%$ & $0,7 \%$ & $2,3 \%$ & $1,4 \%$ & $1,4 \%$ & $\mathbf{0 , 0} \%$ & $8,8 \%$ & $1,4 \%$ & $1,3 \%$ \\
\hline Rio Grande do Norte & $1,1 \%$ & $0,3 \%$ & $1,0 \%$ & $0,7 \%$ & $0,4 \%$ & $1,1 \%$ & $0,4 \%$ & $0,4 \%$ & $0,6 \%$ & $1,4 \%$ & $0,5 \%$ & $0,4 \%$ & $0,5 \%$ & $0,9 \%$ \\
\hline Paraiba & $1,0 \%$ & $0,4 \%$ & $0,7 \%$ & $\mathbf{0 , 8 \%}$ & $0,2 \%$ & $0,1 \%$ & $0,2 \%$ & $0,1 \%$ & $0,4 \%$ & $1,3 \%$ & $0,0 \%$ & $0,2 \%$ & $0,4 \%$ & $\mathbf{0 , 8} \%$ \\
\hline Pernambuco & $3,0 \%$ & $2,3 \%$ & $1,6 \%$ & $1,7 \%$ & $1,7 \%$ & $2,1 \%$ & $1,6 \%$ & $0,6 \%$ & $2,3 \%$ & $2,4 \%$ & $1,1 \%$ & $1,3 \%$ & $1,8 \%$ & $1,3 \%$ \\
\hline Alagoas & $0,8 \%$ & $0,1 \%$ & $0,4 \%$ & $0,5 \%$ & $\mathbf{0 , 1 \%}$ & $0,3 \%$ & $0,2 \%$ & $\mathbf{0 , 1 \%}$ & $0,6 \%$ & $0,2 \%$ & $\mathbf{0 , 0} \%$ & $0,2 \%$ & $\mathbf{0 , 2 \%}$ & $0,5 \%$ \\
\hline Sergipe & $0,8 \%$ & $0,3 \%$ & $0,3 \%$ & $0,4 \%$ & $0,1 \%$ & $0,6 \%$ & $0,3 \%$ & $\mathbf{0 , 0} \%$ & $0,5 \%$ & $0,6 \%$ & $\mathbf{0 , 0} \%$ & $0,2 \%$ & $0,2 \%$ & $0,6 \%$ \\
\hline Bahia & $3,9 \%$ & $1,2 \%$ & $1,8 \%$ & $2,2 \%$ & $1,3 \%$ & $4,0 \%$ & $1,8 \%$ & $2,8 \%$ & $2,2 \%$ & $8,4 \%$ & $1,7 \%$ & $2,3 \%$ & $1,6 \%$ & $0,9 \%$ \\
\hline Northeast & $14,6 \%$ & $6,5 \%$ & $8,3 \%$ & $8,7 \%$ & $5,2 \%$ & $11,6 \%$ & $5,6 \%$ & $7,2 \%$ & $8,5 \%$ & $16,3 \%$ & $5,9 \%$ & $15,9 \%$ & $6,5 \%$ & $1,0 \%$ \\
\hline Minas Gerais & $8,8 \%$ & $5,4 \%$ & $4,1 \%$ & $4,7 \%$ & $6,5 \%$ & $6,3 \%$ & $2,8 \%$ & $3,9 \%$ & $8,6 \%$ & $8,8 \%$ & $\mathbf{8 , 9 \%}$ & $6,6 \%$ & $5,9 \%$ & $1,5 \%$ \\
\hline Espírito Santo & $1,7 \%$ & $1,5 \%$ & $\mathbf{0 , 8 \%}$ & $1,3 \%$ & $1,2 \%$ & $1,0 \%$ & $0,9 \%$ & $0,9 \%$ & $1,8 \%$ & $0,5 \%$ & $0,2 \%$ & $2,9 \%$ & $1,3 \%$ & $1,6 \%$ \\
\hline Rio de Janeiro & $11,2 \%$ & $11,6 \%$ & $18,9 \%$ & $29,1 \%$ & $11,4 \%$ & $18,5 \%$ & $8,7 \%$ & $11,7 \%$ & $8,6 \%$ & $18,6 \%$ & $29,4 \%$ & $8,9 \%$ & $14,8 \%$ & $2,9 \%$ \\
\hline São Paulo & $32,2 \%$ & $51,9 \%$ & $48,8 \%$ & $33,0 \%$ & $53,3 \%$ & $45,5 \%$ & $68,6 \%$ & $53,5 \%$ & $43,3 \%$ & $29,5 \%$ & $20,7 \%$ & $48,5 \%$ & $49,3 \%$ & $3,3 \%$ \\
\hline Southeast & $53,8 \%$ & $70,4 \%$ & $72,6 \%$ & $68,1 \%$ & $72,4 \%$ & $71,2 \%$ & $80,9 \%$ & $70,0 \%$ & $62,3 \%$ & $57,4 \%$ & $59,1 \%$ & $67,0 \%$ & $71,3 \%$ & $2,9 \%$ \\
\hline Paraná & $5,9 \%$ & $7,7 \%$ & $3,7 \%$ & $4,3 \%$ & $3,6 \%$ & $3,4 \%$ & $2,4 \%$ & $7,1 \%$ & $7,0 \%$ & $8,1 \%$ & $9,7 \%$ & $4,9 \%$ & $4,4 \%$ & $1,6 \%$ \\
\hline Santa Catarina & $4,1 \%$ & $2,4 \%$ & $2,5 \%$ & $2,6 \%$ & $4,4 \%$ & $2,5 \%$ & $1,9 \%$ & $6,6 \%$ & $6,5 \%$ & $2,1 \%$ & $0,1 \%$ & $2,5 \%$ & $3,5 \%$ & $1,9 \%$ \\
\hline Rio Grande do Sul & $6,0 \%$ & $6,2 \%$ & $3,8 \%$ & $4,5 \%$ & $5,7 \%$ & $4,7 \%$ & $2,8 \%$ & $2,7 \%$ & $7,9 \%$ & $3,3 \%$ & $5,3 \%$ & $2,6 \%$ & $5,3 \%$ & $1,9 \%$ \\
\hline South & $16,0 \%$ & $16,4 \%$ & $10,1 \%$ & $11,4 \%$ & $13,6 \%$ & $10,6 \%$ & $7,1 \%$ & $16,5 \%$ & $21,3 \%$ & $13,5 \%$ & $15,2 \%$ & $10,0 \%$ & $13,2 \%$ & $1,8 \%$ \\
\hline Mato Grosso do Sul & $1,2 \%$ & $0,5 \%$ & $0,8 \%$ & $0,8 \%$ & $0,4 \%$ & $0,7 \%$ & $0,4 \%$ & $0,2 \%$ & $0,6 \%$ & $1,7 \%$ & $0,6 \%$ & $0,4 \%$ & $0,5 \%$ & $0,9 \%$ \\
\hline Mato Grosso & $1,5 \%$ & $0,3 \%$ & $1,4 \%$ & $0,8 \%$ & $0,6 \%$ & $0,4 \%$ & $0,4 \%$ & $0,8 \%$ & $0,9 \%$ & $0,4 \%$ & $0,1 \%$ & $0,4 \%$ & $0,6 \%$ & $0,9 \%$ \\
\hline Goiás & $2,7 \%$ & $1,4 \%$ & $1,8 \%$ & $1,6 \%$ & $0,9 \%$ & $1,5 \%$ & $0,7 \%$ & $2,1 \%$ & $2,0 \%$ & $2,3 \%$ & $0,3 \%$ & $0,6 \%$ & $1,1 \%$ & $0,9 \%$ \\
\hline Distrito Federal & $4,9 \%$ & $2,8 \%$ & $1,9 \%$ & $5,5 \%$ & $6,4 \%$ & $1,7 \%$ & $3,4 \%$ & $1,6 \%$ & $2,3 \%$ & $1,6 \%$ & $3,2 \%$ & $3,0 \%$ & $5,2 \%$ & $2,3 \%$ \\
\hline Midwest & $10,2 \%$ & $4,9 \%$ & $5,9 \%$ & $8,7 \%$ & $8,3 \%$ & $4,2 \%$ & $4,8 \%$ & $4,6 \%$ & $5,8 \%$ & $6,0 \%$ & $4,3 \%$ & $4,4 \%$ & $7,5 \%$ & $1,6 \%$ \\
\hline TOTAL & 101.491 .948 & 288.125 & 53.630 & 378.568 & 1.224 .553 & 19.631 & 114.788 & 6.188 & 22.308 & 34.441 & 22.032 & 31.970 & 2.196 .234 & $2,2 \%$ \\
\hline$\%$ creative activities in total & $100,0 \%$ & $0,3 \%$ & $0,1 \%$ & $0,4 \%$ & $1,2 \%$ & $0,0 \%$ & $\mathbf{0 , 1} \%$ & $0,0 \%$ & $0,0 \%$ & $0,0 \%$ & $0,0 \%$ & $\mathbf{0 , 0 \%}$ & $2,2 \%$ & \\
\hline$\%$ in creative activities & & $13,1 \%$ & $2,4 \%$ & $17,2 \%$ & $55,8 \%$ & $0,9 \%$ & $5,2 \%$ & $0,3 \%$ & $1,0 \%$ & $1,6 \%$ & $1,0 \%$ & $1,5 \%$ & $100,0 \%$ & \\
\hline
\end{tabular}

Source: Own elaboration based on data from RAIS (2013) 
Table 9- Creative Activities and Income Generation - Personal monthly worker income (R\$) - Data from RAIS (2013)

\begin{tabular}{|c|c|c|c|c|c|c|c|c|c|c|c|c|c|c|c|c|}
\hline & Total & $\begin{array}{c}\text { Publishing } \\
\text { and } \\
\text { Printing }\end{array}$ & $\begin{array}{c}\text { Film, video } \\
\text { and music }\end{array}$ & $\begin{array}{c}\text { Radio and } \\
\text { TV }\end{array}$ & $\begin{array}{c}\text { Software } \\
\text { developme } \\
\text { nt }\end{array}$ & $\begin{array}{l}\text { Architectur } \\
\text { al services }\end{array}$ & $\begin{array}{l}\text { Advertisin } \\
\text { g agencies }\end{array}$ & $\begin{array}{c}\text { Design and } \\
\text { interior } \\
\text { decoration } \\
\end{array}$ & $\begin{array}{c}\text { Photograph } \\
\text { ic and } \\
\text { similar } \\
\text { activities } \\
\end{array}$ & $\begin{array}{c}\text { Performing } \\
\text { activities }\end{array}$ & $\begin{array}{l}\text { Activities } \\
\text { related to } \\
\text { cultural } \\
\text { heritage }\end{array}$ & \begin{tabular}{|c|} 
Activities \\
of \\
membershi \\
p \\
organizatio \\
ns linked \\
to culture \\
and art \\
\end{tabular} & $\begin{array}{c}\text { Sub-total } \\
\text { creative } \\
\text { activities }\end{array}$ & $\begin{array}{c}\text { Creative } \\
\text { activities } \\
\text { /total } \\
\end{array}$ & $\begin{array}{l}\text { Comp } \\
\text { reg total }\end{array}$ & $\begin{array}{c}\text { Comp } \\
\text { reg } \\
\text { creative } \\
\text { activities } \\
\end{array}$ \\
\hline Rondônia & 1.903 & 1.276 & 1.292 & 1.595 & 1.533 & 968 & 1.399 & 909 & 891 & 942 & 1.962 & \begin{tabular}{|l}
687 \\
\end{tabular} & 1.437 & $75,5 \%$ & $91,8 \%$ & $44,7 \%$ \\
\hline Acre & 2.041 & 1.281 & 1.273 & 1.826 & 1.716 & 1.175 & 1.462 & 897 & 802 & 2.214 & 2.111 & 1.491 & 1.723 & $84,4 \%$ & $98,4 \%$ & $53,6 \%$ \\
\hline Amazonas & 2.020 & 1.974 & 1.147 & 2.152 & 1.817 & 1.570 & 1.980 & 1.009 & 914 & 2.383 & 968 & 1.568 & 1.977 & $97,9 \%$ & $97,4 \%$ & $61,5 \%$ \\
\hline Roraima & 2.186 & 1.044 & 951 & 1.824 & 1.949 & 798 & 1.041 & \#DIV/0! & 881 & 679 & 1.326 & 1.910 & 1.513 & $69,2 \%$ & $105,4 \%$ & $47,0 \%$ \\
\hline Pará & 1.900 & 1.755 & 1.110 & 1.621 & 2.764 & 1.355 & 1.729 & 1.028 & 952 & 1.065 & 9.516 & 1.520 & 2.096 & $110,4 \%$ & $91,6 \%$ & $65,2 \%$ \\
\hline Amapá & 2.480 & 960 & 884 & 1.937 & 1.615 & 764 & 1.315 & 621 & 925 & 924 & 941 & 1.033 & 1.454 & $58,6 \%$ & $119,6 \%$ & $45,2 \%$ \\
\hline Tocantins & 1.883 & 1.932 & 1.202 & 1.943 & 1.745 & 1.097 & 1.350 & 732 & 854 & 925 & 1.108 & 674 & 1.679 & $89,2 \%$ & $90,8 \%$ & $52,2 \%$ \\
\hline North & 1.970 & 1.718 & 1.149 & 1.826 & 2.179 & 1.373 & 1.717 & 958 & 914 & 1.945 & 5.840 & 1.436 & 1.888 & $95,9 \%$ & $95,0 \%$ & $58,7 \%$ \\
\hline Maranhão & 1.654 & 1.341 & 1.062 & 1.726 & 1.724 & 1.142 & 1.514 & 1.051 & 798 & 963 & 1.562 & 1.162 & 1.525 & $92,2 \%$ & $79,8 \%$ & $47,4 \%$ \\
\hline Piauí & 1.630 & 1.253 & $\begin{array}{l}997 \\
\end{array}$ & 1.954 & 1.436 & 916 & 1.123 & 786 & 922 & 896 & 1.577 & 1.196 & 1.399 & $85,8 \%$ & $78,6 \%$ & $43,5 \%$ \\
\hline Ceará & 1.542 & 1.574 & 1.117 & 2.043 & 2.300 & 1.628 & 1.508 & 1.664 & 836 & 936 & 698 & 1.365 & 1.864 & $120,9 \%$ & $\mathbf{7 4 , 4 \%}$ & $57,9 \%$ \\
\hline Rio Grande do Norte & 1.736 & 1.545 & 1.071 & 1.852 & 2.426 & 1.894 & 1.366 & 866 & 839 & 1.210 & 1.014 & 936 & 1.798 & $103,6 \%$ & $83,7 \%$ & $55,9 \%$ \\
\hline Paraíba & 1.520 & 1.245 & 1.215 & 1.768 & 2.020 & 897 & 1.224 & 763 & 867 & 1.066 & \#DIV/0! & 979 & 1.583 & $104,1 \%$ & $73,3 \%$ & $49,2 \%$ \\
\hline Pernambuco & 1.703 & 2.251 & 1.090 & 2.531 & 2.943 & 2.078 & 1.917 & 1.009 & 816 & 1.157 & 1.615 & 1.396 & 2.390 & $140,3 \%$ & $82,1 \%$ & $74,3 \%$ \\
\hline Alagoas & 1.548 & 1.095 & 1.002 & 1.990 & 1.545 & 1.157 & 924 & 1.061 & 867 & 886 & 745 & 877 & 1.475 & $95,3 \%$ & $74,7 \%$ & $45,9 \%$ \\
\hline Sergipe & 1.885 & 1.504 & 920 & 2.120 & 1.714 & 936 & 1.116 & 489 & 892 & 1.288 & 767 & 1.160 & 1.580 & $83,8 \%$ & $90,9 \%$ & $49,1 \%$ \\
\hline Bahia & 1.731 & 1.764 & 1.152 & 2.514 & 2.090 & 2.180 & 1.888 & 1.370 & 893 & 1.897 & 1.126 & 1.599 & 1.989 & $114,9 \%$ & $83,5 \%$ & $61,8 \%$ \\
\hline Northeast & 1.664 & 1.723 & 1.099 & 2.140 & 2.348 & 1.643 & 1.607 & 1.284 & 854 & 1.396 & 1.342 & 1.330 & 1.923 & $115,6 \%$ & $80,2 \%$ & $59,8 \%$ \\
\hline Minas Gerais & 1.762 & 2.098 & 1.170 & 2.211 & 3.107 & 1.587 & 1.589 & 1.118 & 942 & 1.506 & 2.608 & 2.068 & 2.489 & $141,2 \%$ & $85,0 \%$ & $77,4 \%$ \\
\hline Espírito Santo & 1.851 & 2.250 & 1.230 & 2.359 & 3.059 & 1.482 & 2.153 & 1.061 & 983 & 997 & 1.596 & 1.693 & 2.484 & $134,2 \%$ & $89,3 \%$ & $77,2 \%$ \\
\hline Rio de Janeiro & 2.467 & 3.089 & 2.136 & 6.703 & 3.906 & 2.245 & 3.799 & 1.782 & 1.187 & 1.989 & 6.233 & 2.003 & 4.083 & $165,5 \%$ & $119,0 \%$ & $126,9 \%$ \\
\hline São Paulo & 2.328 & 3.490 & 2.360 & 3.717 & 4.422 & 2.899 & 5.096 & 1.932 & 1.465 & 2.190 & 2.913 & 1.919 & 3.925 & $168,6 \%$ & $112,3 \%$ & $122,0 \%$ \\
\hline Southeast & 2.219 & 3.218 & 2.156 & 4.281 & 4.146 & 2.495 & 4.521 & 1.814 & 1.304 & 1.968 & 3.859 & 1.932 & 3.738 & $168,4 \%$ & $107,0 \%$ & $116,2 \%$ \\
\hline Paraná & 1.927 & 2.453 & 1.332 & 2.498 & 2.474 & 1.758 & 2.371 & 1.958 & 1.223 & 2.643 & 2.180 & 1.338 & 2.345 & $121,7 \%$ & $92,9 \%$ & $72,9 \%$ \\
\hline Santa Catarina & 1.865 & 1.758 & 1.406 & 1.882 & 3.100 & 1.541 & 1.806 & 2.630 & 1.191 & 1.259 & 1.483 & 1.235 & 2.463 & $132,1 \%$ & $89,9 \%$ & $76,6 \%$ \\
\hline Rio Grande do Sul & 1.982 & 1.816 & 1.398 & 1.884 & 3.789 & 1.365 & 2.275 & 1.568 & 1.073 & 1.301 & 2.868 & 1.138 & 2.595 & $130,9 \%$ & $95,6 \%$ & $80,7 \%$ \\
\hline South & 1.931 & 2.058 & 1.375 & 2.075 & 3.127 & 1.514 & 2.159 & 2.086 & 1.154 & 1.861 & 2.370 & 1.255 & 2.472 & $128,0 \%$ & $93,1 \%$ & $76,9 \%$ \\
\hline Mato Grosso do Sul & 1.897 & 1.432 & 1.340 & 1.926 & 1.639 & 1.336 & 1.246 & 1.136 & 984 & 1.551 & 2.196 & 1.158 & 1.617 & $85,2 \%$ & $91,5 \%$ & $50,3 \%$ \\
\hline Mato Grosso & 1.895 & 1.333 & 1.169 & 1.824 & 3.078 & 1.014 & 1.184 & 1.129 & 942 & 1.105 & 1.778 & 1.382 & 2.092 & $110,4 \%$ & $91,4 \%$ & $65,0 \%$ \\
\hline Goiás & 1.791 & 1.898 & 1.346 & 2.129 & 2.105 & 1.168 & 1.676 & 1.393 & 961 & 1.369 & 1.153 & 1.232 & 1.912 & $106,8 \%$ & $86,4 \%$ & $59,5 \%$ \\
\hline Distrito Federal & 3.783 & 3.681 & 1.385 & 5.336 & 4.146 & 1.445 & 3.734 & 1.318 & 1.222 & 1.599 & 3.653 & 2.081 & 4.046 & $106,9 \%$ & $182,4 \%$ & $125,8 \%$ \\
\hline Midwest & 2.438 & 2.411 & 1.309 & 3.290 & 3.447 & 1.271 & 2.503 & 1.302 & 1.047 & 1.453 & 2.846 & 1.715 & 3.004 & $123,2 \%$ & $117,6 \%$ & $93,4 \%$ \\
\hline TOTAL & 2.073 & 2.725 & 1.792 & 3.356 & 3.751 & 2.099 & 3.636 & 1.742 & 1.190 & 1.795 & 3.302 & 1.694 & 3.216 & $155,1 \%$ & $100,0 \%$ & $100,0 \%$ \\
\hline$\%$ creative activities in total & $100,0 \%$ & $131,4 \%$ & $86,4 \%$ & $161,8 \%$ & $180,9 \%$ & $101,2 \%$ & $175,3 \%$ & $84,0 \%$ & $57,4 \%$ & $86,6 \%$ & $159,2 \%$ & $81,7 \%$ & $155,1 \%$ & & & \\
\hline$\%$ in creative activities & & $84,7 \%$ & $55,7 \%$ & $104,3 \%$ & $116,6 \%$ & $65,3 \%$ & $113,0 \%$ & $54,2 \%$ & $37,0 \%$ & $55,8 \%$ & $102,7 \%$ & $52,7 \%$ & $100,0 \%$ & & & \\
\hline
\end{tabular}

Source: Own elaboration based on data from RAIS (2013) 
Table 10 - Sectoral Trend of Indicators - 2006-2010 (data from RAIS)

\begin{tabular}{|c|c|c|c|c|c|c|c|c|c|c|c|c|c|c|c|}
\hline & Year & Total & $\begin{array}{c}\text { Publishing } \\
\text { and Printing }\end{array}$ & $\begin{array}{l}\text { Film, video } \\
\text { and music }\end{array}$ & $\begin{array}{l}\text { Radio and } \\
\text { TV } \\
\end{array}$ & $\begin{array}{c}\text { Software } \\
\text { development }\end{array}$ & \begin{tabular}{|c} 
Architectural \\
services
\end{tabular} & $\begin{array}{c}\text { Advertising } \\
\text { agencies }\end{array}$ & $\begin{array}{l}\text { Design and } \\
\text { interior } \\
\text { decoration } \\
\end{array}$ & $\begin{array}{c}\text { Photographic } \\
\text { and similar } \\
\text { activities }\end{array}$ & $\begin{array}{c}\text { Performing } \\
\text { activities }\end{array}$ & $\begin{array}{c}\text { Activities } \\
\text { related to } \\
\text { cultural } \\
\text { heritage } \\
\end{array}$ & $\begin{array}{c}\text { Organization } \\
\text { s linked to } \\
\text { culture and } \\
\text { art }\end{array}$ & $\begin{array}{c}\text { Creative } \\
\text { Activities } \\
\end{array}$ & $\begin{array}{c}\begin{array}{c}\% \text { of } \\
\text { Creative } \\
\text { activities }\end{array} \\
\end{array}$ \\
\hline \multirow{4}{*}{ Number of workers } & 2006 & 35.155 .249 & 109.362 & 21.056 & 82.490 & 158.747 & $\begin{array}{r}9.066 \\
\end{array}$ & 26.877 & 1.862 & 12.601 & 11.740 & 6.158 & 12.426 & 452.385 & $1,29 \%$ \\
\hline & 2010 & 44.068.355 & 114.910 & 24.528 & 108.177 & 255.876 & 12.132 & 30.896 & 2.354 & 17.931 & 15.486 & 6.832 & 17.516 & 606.638 & $1,38 \%$ \\
\hline & 2013 & 48.948.433 & 105.744 & 29.921 & 112.820 & 326.438 & 9.351 & 31.574 & 3.552 & 18.741 & 19.190 & 6.673 & 18.876 & 682.880 & $1,40 \%$ \\
\hline & Var & $39 \%$ & $-3 \%$ & $42 \%$ & $37 \%$ & $106 \%$ & $3 \%$ & $17 \%$ & $91 \%$ & $49 \%$ & $63 \%$ & $8 \%$ & $52 \%$ & $51 \%$ & $8 \%$ \\
\hline \multirow{4}{*}{$\begin{array}{l}\text { Labor income - } \\
\text { Total Monthly } \\
\text { Payed (R\$ 1000) }\end{array}$} & 2006 & 41.116 .759 & 180.808 & 22.560 & 168.725 & 345.763 & 12.905 & 49.115 & 1.286 & 8.872 & 11.809 & 10.172 & 12.181 & 824.197 & $2,00 \%$ \\
\hline & 2010 & 69.999.187 & 250.311 & 34.090 & 284.142 & 740.993 & 23.991 & 79.980 & 3.047 & 16.884 & 21.200 & 18.016 & 23.105 & 1.495 .760 & $2,14 \%$ \\
\hline & 2013 & 101.491 .948 & 288.125 & 53.630 & 378.568 & \begin{tabular}{|l|}
1.224 .553 \\
\end{tabular} & 19.631 & 114.788 & 6.188 & 22.308 & 34.441 & 22.032 & 31.970 & 2.196 .234 & $2,16 \%$ \\
\hline & Var & $147 \%$ & $59 \%$ & $138 \%$ & $124 \%$ & $254 \%$ & $52 \%$ & $134 \%$ & 381\% & $151 \%$ & $192 \%$ & $117 \%$ & $162 \%$ & $166 \%$ & $8 \%$ \\
\hline \multirow{4}{*}{$\begin{array}{l}\text { Personal worker } \\
\text { income (R\$) }\end{array}$} & 2006 & 1.170 & 1.653 & 1.071 & 2.045 & \begin{tabular}{|l|}
2.178 \\
\end{tabular} & 1.423 & 1.827 & 691 & 704 & 1.006 & 1.652 & 980 & 1.822 & 1,56 \\
\hline & 2010 & 1.588 & 2.178 & 1.390 & 2.627 & 2.896 & 1.977 & 2.589 & 1.294 & 942 & 1.369 & 2.637 & 1.319 & 2.466 & 1,55 \\
\hline & 2013 & 2.073 & 2.725 & 1.792 & 3.356 & 3.751 & 2.099 & 3.636 & 1.742 & 1.190 & 1.795 & 3.302 & 1.694 & 3.216 & 1,55 \\
\hline & Var & $77,3 \%$ & $64,8 \%$ & $67,3 \%$ & $64,1 \%$ & 72,2\% & $47,5 \%$ & $98,9 \%$ & $152,2 \%$ & $69,1 \%$ & $78,4 \%$ & $99,9 \%$ & $72,8 \%$ & $76,5 \%$ & 0,99 \\
\hline
\end{tabular}

Source: Own elaboration based on data from RAIS (2006, 2010, 2013) 


\section{3 - Sectoral and Regional Concentration Indexes}

Another relevant aspect refers to the sectoral concentration of employment and remuneration among the different creative activities, analyzed according to different territorial levels (country, regions and federative states). To measure this evolution between 2006 and 2013, we consider the evolution of a sectoral concentration index, the Herfindhal-Hirschman Index, which assumes a higher value (close to 1) the higher the concentration. Concerning the country as a whole, there was an increase in that index for jobs and remunerations, indicating an increase in the relevance of the most dynamic activities mentioned above: for total establishments, this index rose by $12.9 \%$ in that period; for formal jobs this increase was 28.3\%; for the remunerations the growth was even higher, 33.4\% (Table 11). Regionally, there is a more intense growth of the sectoral concentration of creative activities in the more developed regions. The South region is where these rates have risen more: there was an increase of $39.2 \%$ of the sectoral concentration index for jobs and $72.6 \%$ for remunerations. In the Southeast also occurred a significant increase of those indexes, which reached $27.3 \%$ for jobs and $29.9 \%$ for remunerations a. In these regions, those rates have risen for all federative states over the period. In contrast, in the Northeast, North and Midwest regions the indexes of sectoral concentration to jobs and remunerations had a much lower growth over the period considered, and some federative states experienced a decrease of those indexes.

Table 11 - Index of sectoral concentration among cultural activities - Herfindhal Index (HHI) - 2006, 2010 and 2013

\begin{tabular}{|c|c|c|c|c|c|c|c|c|c|}
\hline & \multicolumn{5}{|c|}{ Number of workers } & \multicolumn{4}{|c|}{ Labor income - total monthly payments. } \\
\hline & Census 2010 & RAIS 2006 & RAIS 2010 & RAIS 2013 & var RAIS & RAIS 2006 & RAIS 2010 & RAIS 2013 & var RAIS \\
\hline Acre & 0,2577 & 0,2596 & 0,2670 & 0,2342 & $-9,8 \%$ & 0,3245 & 0,3496 & 0,2770 & $-14,7 \%$ \\
\hline Roraima & 0,1628 & 0,2777 & 0,2769 & 0,3348 & $20,6 \%$ & 0,3887 & 0,3461 & 0,4345 & $11,8 \%$ \\
\hline Pará & 0,1827 & 0,1793 & 0,1851 & 0,1748 & $-2,5 \%$ & 0,2051 & 0,1880 & 0,1773 & $-13,6 \%$ \\
\hline Amapá & 0,1705 & 0,2668 & 0,3308 & 0,2076 & $-22,2 \%$ & 0,3334 & 0,4103 & 0,3046 & $-8,6 \%$ \\
\hline Maranhão & 0,1818 & 0,2369 & 0,2451 & 0,2399 & $1,3 \%$ & 0,3088 & 0,2758 & 0,2888 & $-6,5 \%$ \\
\hline Piauí & 0,1827 & 0,1936 & 0,1829 & 0,1517 & $-21,6 \%$ & 0,2593 & 0,2244 & 0,1886 & $-27,3 \%$ \\
\hline Ceará & 0,2040 & 0,2085 & 0,2060 & 0,2427 & $16,4 \%$ & 0,2831 & 0,2878 & 0,3223 & $13,8 \%$ \\
\hline Rio Grande do Norte & 0,2001 & 0,1812 & 0,1718 & 0,2025 & $11,8 \%$ & 0,2247 & 0,1991 & 0,2846 & $26,6 \%$ \\
\hline Paraíba & 0,1929 & 0,2884 & 0,2295 & 0,2240 & $-22,3 \%$ & 0,3004 & 0,2699 & 0,2705 & $-9,9 \%$ \\
\hline Pernambuco & 0,2007 & 0,1918 & 0,1917 & 0,2543 & $32,6 \%$ & 0,2364 & 0,2499 & 0,3445 & $45,8 \%$ \\
\hline Minas Gerais & 0,1982 & 0,3185 & 0,2536 & 0,2965 & $-6,9 \%$ & 0,3421 & 0,3265 & 0,4179 & $22,1 \%$ \\
\hline Espírito Santo & 0,2190 & 0,2074 & 0,2701 & 0,2703 & $30,3 \%$ & 0,2910 & 0,3570 & 0,3592 & $23,4 \%$ \\
\hline Rio de Janeiro & 0,1965 & 0,2061 & 0,2359 & 0,2691 & $30,6 \%$ & 0,2721 & 0,2960 & 0,3120 & $14,7 \%$ \\
\hline São Paulo & 0,2151 & 0,2521 & 0,2925 & 0,3310 & $31,3 \%$ & 0,3032 & 0,3560 & 0,4011 & $32,3 \%$ \\
\hline Southeast & 0,2058 & 0,2439 & 0,2720 & 0,3105 & $27,3 \%$ & 0,2845 & 0,3258 & 0,3694 & $29,9 \%$ \\
\hline Paraná & 0,2062 & 0,1867 & 0,2155 & 0,2666 & $42,8 \%$ & 0,2119 & 0,2502 & 0,2935 & $38,5 \%$ \\
\hline Santa Catarina & 0,2242 & 0,2001 & 0,2882 & 0,3470 & $73,4 \%$ & 0,2562 & 0,4104 & 0,4987 & $94,6 \%$ \\
\hline Rio Grande do Sul & 0,1928 & 0,2489 & 0,2363 & 0,2635 & $5,8 \%$ & 0,2559 & 0,2844 & 0,4071 & $59,1 \%$ \\
\hline South & 0,2043 & 0,2022 & 0,2334 & 0,2815 & $39,2 \%$ & 0,2214 & 0,2906 & 0,3821 & $72,6 \%$ \\
\hline Mato Grosso do Sul & 0,1787 & 0,2067 & 0,2255 & 0,2504 & $21,1 \%$ & 0,2541 & 0,2566 & 0,2711 & $6,7 \%$ \\
\hline Mato Grosso & 0,1906 & 0,2024 & 0,2092 & 0,2445 & $20,8 \%$ & 0,2567 & 0,2446 & 0,3885 & $51,3 \%$ \\
\hline Goiás & 0,1950 & 0,2642 & 0,3212 & 0,2506 & $-5,1 \%$ & 0,2841 & 0,3100 & 0,2940 & $3,5 \%$ \\
\hline
\end{tabular}

Source: Own elaboration based on data from Census (2010) and RAIS (2006, 2010, 2013)

As the most dynamic creative activities, in terms of growth rates, tend to be concentrated in more developed regions and federative states, an expected consequence would be a process of spatial concentration of these activities, measured by an index of territorial concentration of creative activities. These trends can be evaluated considering the evolution of territorial concentration indexes (HerfindhalHirschman type) for the different creative activities between 2006 and 2013, calculated to jobs, remunerations and establishments (Table 12). For the set of creative activities, the growth of the spatial concentration is less evident: for the jobs, the spatial concentration index increased $11.0 \%$ and for the remunerations, this growth was 3.3\%. However, in some creative activities the growth of the spatial 
concentration is more evident, as in the case of Organizations linked to culture and art, Photographic and similar activities and Advertising agencies. In contrast, to other activities occurred an decrease in spatial concentration, as in the case of Film, video and music, Publishing and Printing, Performing activities and Activities related to cultural heritage.

Table 12 - Index of regional concentration based on distribution among federative states Herfindhal Index (HHI) - 2006, 2010 and 2013

\begin{tabular}{|c|c|c|c|c|c|c|c|c|}
\hline & \multicolumn{4}{|c|}{ Number of workers } & \multicolumn{4}{|c|}{ Labor income - total monthly payments. } \\
\hline & 2006 & 2010 & 2013 & Var & 2006 & 2010 & 2013 & Var \\
\hline Total - Overall Activities & 0,1250 & 0,1234 & 0,1202 & $-3,9 \%$ & 0,1552 & 0,1468 & 0,1403 & $-9,6 \%$ \\
\hline Publishing and Printing & 0,2096 & 0,2048 & 0,2003 & $-4,5 \%$ & 0,3087 & 0,2982 & 0,2979 & $-3,5 \%$ \\
\hline Radio and TV & 0,1323 & 0,1426 & 0,1328 & $0,4 \%$ & 0,2154 & 0,2196 & 0,2051 & $-4,8 \%$ \\
\hline Software development & 0,2167 & 0,2481 & 0,2368 & $9,3 \%$ & 0,3158 & 0,3340 & 0,3125 & $-1,0 \%$ \\
\hline Architectural services & 0,1636 & 0,1732 & 0,1590 & $-2,8 \%$ & 0,2217 & 0,2197 & 0,2528 & $14,0 \%$ \\
\hline Design and interior decoration & 0,3118 & 0,2040 & 0,2605 & $-16,4 \%$ & 0,3444 & 0,2746 & 0,3142 & $-8,8 \%$ \\
\hline Photographic and similar activities & 0,1336 & 0,2148 & 0,1639 & $22,7 \%$ & 0,2052 & 0,2849 & 0,2202 & $7,3 \%$ \\
\hline Performing activities & 0,1500 & 0,1329 & 0,1169 & $-22,1 \%$ & 0,1830 & 0,1623 & 0,1501 & $-18,0 \%$ \\
\hline Activities related to cultural heritage & 0,1771 & 0,1424 & 0,1266 & $-28,5 \%$ & 0,2885 & 0,1606 & 0,1687 & $-41,5 \%$ \\
\hline Organizations linked to culture and art & 0,0987 & 0,1560 & 0,2146 & $117,5 \%$ & 0,1276 & 0,1943 & 0,2627 & $105,9 \%$ \\
\hline Sub-total creative activities & 0,1781 & 0,2014 & $\mathbf{0 , 1 9 7 7}$ & $11,0 \%$ & 0,2699 & 0,2851 & 0,2788 & $3,3 \%$ \\
\hline
\end{tabular}

Source: Own elaboration based on data from RAIS $(2006,2010,2013)$

\section{4 - Concluding Remarks}

In the last decade, Brazil has tried to establish a comprehensive to foster the development of creative actives, which would be reflected in the creation of the Secretariat of the Creative Economy and in the design public policies that tried to amplify the impacts of those actives as a mean to reduce socioeconomic and regional inequalities. These inequalities are also reflected in an interregional dimension, due to the presence of regions that historically concentrated more wealth and have better social indicators (South and Southeast) while there are other less dynamic regions with highest levels of poverty, most notably the Northeast. In this perspective, a relevant issue refers to the effective potential of the strengthening of creative activities to contribute to the reduction of regional inequality, spreading the dissemination of those activities throughout the territory, especially in the direction of less favored regions.

The analysis pointed the evolution of the sectoral concentration of employment, remuneration and establishments among the different creative activities, according to different territorial levels (country, regions and federative states). Between 2006 and 2013, to the country as a whole, there was an increase in sectoral concentration for jobs, remunerations and establishments, indicating an increase in the relevance of the most dynamic creative activities. Regionally, there is a more intense growth of the sectoral concentration of creative activities in the more developed regions. The South region is where these rates have risen more, followed by the Southeast. In these regions, those rates have risen for all federative states over the period. In contrast, in the Northeast, North and Midwest the index of sectoral concentration to jobs, remunerations and establishments had a much lower growth over the period considered, and some federative states experienced a decrease those rates.

The other side of this process was the growth of the index of regional concentration for the different creative activities between 2006 and 2013, calculated to jobs, remunerations and establishments. For the set of creative activities, the increased of the spatial concentration is less evident: for the jobs, the spatial concentration index increased $11.0 \%$; for the remunerations, this growth was $3.3 \%$ and for the number of establishments a decrease of $0.6 \%$ occurred. In some creative activities the growth of the spatial concentration is more evident, as in the case of Organizations linked to culture and art, Photographic and similar activities and Advertising agencies. In contrast, in other activities there was evidence of a decreased in territorial concentration, as in the case of Film, video and music, Publishing and Printing, Performing activities and Activities related to cultural heritage. 
Articulating these trends, it is possible to suggest that there is an ongoing process of regional specialization in the distribution of creative activities in Brazil, combining a greater sectoral specialization - which tend to be more intense for developed regions - with the prospect of some regional decentralization induced by cultural-based activities. In general, the data suggest that the regional decentralization of competences in creative activities in the direction of less developed regions is relatively limited, with the more developed regions remained more specialized in areas with higher digital and technological content, while the less developed regions being relatively more specialized in areas related to the cultural heritage. In this sense, concerning the recent Brazilian experience, the impact of the creative industries to the reduction of regional inequalities tended to be partial. The enlargement of the impact of digital technologies tend affect more directly activities relatively concentrated in more developed regions. On the other hand, the strengthening of the links between cultural diversity, traditions, creative industries and local development open opportunities to exploit the richness of cultural heritage of less developed regions.

To reduce this imbalance, the strengthening of territorial nucleons of dynamic creative activities, with the support of local institutions and of the S\&T infrastructure seem to be very important, reinforcing the relevance of comprehensive policies well-adapted to very diverse local realities. The spread of the most dynamic creative activities with higher digital and technological content for the less developed regions seems to be particularly important. This effort should integrate the impact of new digital-based technologies with the strengthening of the economic potential of local and regional cultural heritage. In this sense, a critical aim to the policies would be the improvement of the professional qualification of the workers in those activities, in order to amplify the possibilities of productive inclusion of the population. It is also necessary to promote the recovery, protection and promotion of the diversity of national cultural expressions to ensure their originality, their strength and their potential to generate an inclusive socioeconomic growth.

\section{Bibliography}

CASSIOLATO, J.E. (org.) (2010) Perspectivas do Investimento na Economia do Conhecimento. Projeto PIB Perspectivas do Investimento no Brasil, v.3. Autores: Gadelha, C.A.G., Albuquerque, E.M., Tigre, P.B., Cavalcanti, P.F.M.B. Rio de Janeiro: Synergia.

CAVES , R. E. (2002) Creative industries - Contracts between art and commerce. Cambridge: Harvard University Press.

CUNNINGHAM, S. D. From cultural to creative industries: theory, industry, and policy implications. Media international Australia incorporating culture and policy. Quarterly Journal of Media Research and Resources, $\mathrm{n}$. 102, p. 54-65, 2002.

DCMS - UK Department of Culture, Media and Sport \& Creative Industries Taskforce (1998). Creative Industries Mapping Document 1998. Londres: Department for Culture, Media and Sport.

DCMS - UK Department of Culture, Media and Sport \& Creative Industries Taskforce (2001). Creative Industries Mapping Document 2001. Londres: Department for Culture, Media and Sport.

FIRJAN (2011) A Cadeia da Indústria Criativa no Brasil - Edição 2011. Nota Técnica da Gerência de Estudos Econômicos. n¹0 Outubro/2011. Rio de Janeiro: Sistema Firjan.

FIRJAN (2012) Indústria Criativa: Mapeamento da Indústria Criativa no Brasil. Rio de Janeiro: Sistema Firjan. FIRJAN (2014) Indústria Criativa: Mapeamento da Indústria Criativa no Brasil. Rio de Janeiro: Sistema Firjan.

FLORIDA, R. The flight of the creative class: the new global competition for talent. [S.l.] HarperBusiness, 2007.

FLORIDA, R. (2002) The Rise of the creative class. Nova Iorque: Basic Books.

FLORIDA, R. (2005). Cities and the Creative Class. New York, NY: Routledge.

FLORIDA, R. (2006). The Flight of the Creative Class: The New Global Competition for Talent. New York, NY: Harper Business.

GALLOWAY, S. ; DUNLOP, S. "Critique of definitions of the cultural and creative industries in Public policy", International Journal of Cultural Policy, Vol. 13, No. 1, 2007 
GARNHAM, N. (2005). "From Cultural to Creative Industries: An analysis of the implications of the "creative industries' approach to arts and media policy making in the United Kingdom”, The International Journal of Cultural Policy, 11(1):15-29.

HAGOORT, G.; THOMASSEN, A. On the entrepreneurial principles of the cultural and creative industries. 2007.

HARTLEY, J. (2005) Creative Industries. Oxford: Blackwell Publishing.

HOWKINS, J. (2001) The Creative economy - How people make money from ideas. Londres: Penguin Books.

MINISTÉRIO DA CULTURA - Plano da Secretaria da Economia Criativa: políticas, diretrizes e ações, 2011 - 2014, Brasília, Ministério da Cultura, 2011.

NESTA, (2006). Creating Growth: How the UK Can Develop World Class Creative Businesses. Retrieved from http://www.nesta.org.uk/library/documents/Creating-Growth.pdf.

NESTA, (2007). Staying Ahead: The Economic Performance of the UK's Creative Industries. Retrieved from http://www.theworkfoundation.com/research/publications

NESTA, (2008). The Art of Innovation: How Fine Arts Graduates Contribute to Innovation. Retrieved from http://www.nesta.org.uk/library/documents/Report\%2016\%20-\%20Art\%20of\%20Innovation\%20v11.pdf

O’REGAN, T. (2001) Cultural Policy: Rejuvenate or Wither, Professorial Lecture, Griffith University, Queensland, Australia

OAKLEY, K. (2009). “The Disappearing Arts: Creativity and Innovation after the Creative Industries.” International Journal of Cultural Policy, 15(4), 403-41. Creative Economy Literature Review February 14, 2012

OLIVEIRA, J.M.; ARAUJO, B.C.; SILVA, L.V. "Panorama da Economia Criativa no Brasil", Texto para discussão 1880, Instituto de Pesquisa Econômica, Aplicada.- Brasília : Rio de Janeiro : Ipea, 2013

ONU, UNCTAD; Creative Economy Report 2013 Special Edition. UN, 2013

ONU, UNCTAD; Creative Economy Report 2010 - Creative Economy: A Feasible Development Option. UN, 2010

ONU, UNCTAD; Creative Economy Report 2008 - Creative Economy: A Feasible Development Option. UN, 2008

QUARTESAN, A.; ROMIS, M.; LANZAFAME, F. "Cultural Industries in Latin America and the Caribbean: Challenges and Opportunities", CEPAL, september 2007

RESTREPO, F.B.; MÁRQUEZ, I.D. "The Orange Economy: and infinity opportunity", IDB- Inter-American Development Bank, 2013

SCOTT, A. (2004). Cultural Industries and the Production of Culture. London, Routledge.

SELA - Sistema Económico Latinoamericano y del Caribe. "Promotion of cultural and creative industries in Latin America and the Caribbean”, Permanent Secretariat of SELA, Caracas, Venezuela, June 2011

SISTEMA FIRJAN, “Mapeamento da Indústria Criativa no Brasil”, 2012.

SISTEMA FIRJAN, "Mapeamento da Indústria Criativa no Brasil”, 2014.

SISTEMA FIRJAN; “A Cadeia da Indústria Criativa no Brasil”, 2008.

STOLARICK, K., MELANDER, C., FLORIDA, R. (2010) “Creative Jobs, Industries and Places”. Industry and Innovation. 17(1), pp.1-4.

STONEMAN, P. Soft innovation: economics, product aesthetics, and the creative industries. Oxford, 2010.

THROSBY, D. (2001). Economics and Culture. Cambridge: Cambridge University Press.

TOWSE, R. (ed.) (2003) A Handbook of Cultural Economics. Cheltenham: Edward Elgar.

UNESCO - UNITED NATIONS EDUCATIONAL, SCIENTIFIC AND CULTURAL ORGANIZATION. Unesco world report: investing in cultural diversity and intercultural dialogue. Unesco, 2009.

UNESCO - UNITED NATIONS EDUCATIONAL, SCIENTIFIC AND CULTURAL ORGANIZATION. Creative Economy Report: Widening Local Development Pathways. Unesco, 2014.

UNESCO. (2011). What is the Creative Cities Network?

WIPO - WORLD INTELLECTUAL PROPERTY ORGANIZATION. Guide on surveying the economic contribution of the copyright industries. Wipo, 2003. 